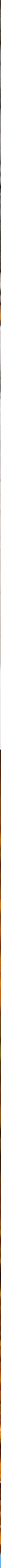

Ontwikkeling klimaatlat veehouderij 



\title{
Ontwikkeling klimaatlat veehouderij
}

H. Mollenhorst ${ }^{1}$, A. de Ridder ${ }^{2}$, C.M. Groenestein ${ }^{1}$

\author{
${ }^{1}$ Wageningen University and Research, Wageningen Livestock Research \\ ${ }^{2}$ SMK
}

Dit onderzoek is uitgevoerd door Wageningen Livestock Research, in opdracht van en gefinancierd door het Ministerie van Landbouw, Natuur en Voedselkwaliteit, in het kader van het Beleidsondersteunend onderzoek thema 'Klimaatenveloppe - Methaanemissie veehouderij - Klimaatlat' (projectnummer BO-53-003-024)

Wageningen Livestock Research

Wageningen, februari 2020 
Mollenhorst, H., A. de Ridder, C.M. Groenestein, 2020. Ontwikkeling klimaatlat veehouderij. Wageningen Livestock Research, Report 1236.

Samenvatting NL De Maatlat Duurzame Veehouderij (MDV) bevat een Klimaatlat waarin gecertificeerde maatregelen voor energiebesparing en opwekking van duurzame energie zijn opgenomen. Het was gewenst om deze uit te breiden met maatregelen waarmee de reductie van broeikasgasemissies uit stallen en mestopslagen via de bouw gestimuleerd kan worden. Na eerder uitgevoerd literatuuronderzoek waren er nog onduidelijkheden over relaties tussen methaan-, lachgasen ammoniakemissies tijdens diverse processen of opslagomstandigheden. In zes deelprojecten zijn deze relaties onderzocht. Op basis van de resultaten zijn enkele maatregelen opgenomen in de Klimaatlat. De nu opgenomen maatregelen beperken zich tot drijfmestsystemen, waarbij snelle verwijdering van mest uit het dierverblijf gekoppeld wordt aan emissiearme opslag of mestverwerking.

Summary UK The 'Yardstick Sustainable Animal Husbandry' (in Dutch: Maatlat Duurzame Veehouderij, MDV) already contained a 'Climate Yardstick' (in Dutch: Klimaatlat) with some certified measures regarding energy saving and generation of renewable energy. It was desirable to extend this with measures to stimulate the reduction of greenhouse gas emissions from animal houses and manure storages. Some uncertainties about relations between methane, nitrous oxide and ammonia emissions remained after an earlier performed literature review. These relationships were investigated in 6 subprojects. Based on these results some measures were added to the certification scheme. These added measures, however, are limited to systems with liquid manure, in which quick removal of manure from the animal houses is coupled with low-emission storage or manure processing.

Dit rapport is gratis te downloaden op https://doi.org/10.18174/515230 of op

www.wur.nl/livestock-research (onder Wageningen Livestock Research publicaties).

(C) 2020 Wageningen Livestock Research

Postbus 338, 6700 AH Wageningen, T 03174839 53, E info.livestockresearch@wur.nl, www.wur.nl/livestock-research. Wageningen Livestock Research is onderdeel van Wageningen University \& Research.

Wageningen Livestock Research aanvaardt geen aansprakelijkheid voor eventuele schade voortvloeiend uit het gebruik van de resultaten van dit onderzoek of de toepassing van de adviezen.

Alle rechten voorbehouden. Niets uit deze uitgave mag worden vermenigvuldigd en/of openbaar gemaakt worden door middel van druk, fotokopie, microfilm of op welke wijze dan ook zonder voorafgaande toestemming van de uitgever of auteur.

Wageningen Livestock Research is NEN-EN-ISO 9001:2015 gecertificeerd. Op al onze onderzoeksopdrachten zijn de Algemene Voorwaarden van de Animal Sciences Group van toepassing. Deze zijn gedeponeerd bij de Arrondissementsrechtbank Zwolle. 


\section{Inhoud}

$\begin{array}{ll}\text { Samenvatting } & 5\end{array}$

1

Inleiding

$\begin{array}{ll}\text { Drijfmestsystemen } & 11\end{array}$

$2.1 \quad$ Maatregel korte verblijftijd drijfmest in stalsysteem $\quad 11$

2.2 Maatregel mestvergistingsinstallatie $\quad 12$

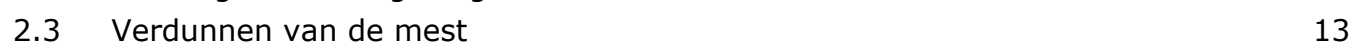

2.4 Koeldeksysteem / mestkoeling 13

2.5 Aanzuren van mest 14

$\begin{array}{lll}2.6 & \text { Conclusie } & 15\end{array}$

3

Mestmixen

16

$\begin{array}{ll}\text { Niet te stimuleren maatregelen } & 17\end{array}$

$\begin{array}{lll}4.1 & \text { Inleiding, doelstelling } & 17\end{array}$

$\begin{array}{lll}4.2 & \text { Resultaat } & 17\end{array}$

4.2.1 Droge mest in ligboxen $\quad 17$

4.2.2 Open mestverwerkingssystemen 17

$\begin{array}{ll}4.2 .3 \text { Potstallen } & 18\end{array}$

4.2.4 Vrijloopstallen 18

4.2.5 Compostering 18

$\begin{array}{ll}4.2 .6 \text { Beluchting (dunne fractie) } & 19\end{array}$

$5 \quad$ Effecten in de mestketen $\quad 20$

$\begin{array}{lll}5.1 & \text { Inleiding, doelstelling } & 20\end{array}$

$\begin{array}{lll}5.2 & \text { Resultaat } & 20\end{array}$

5.2.1 Opslag drijfmest (referentie situatie) 20

5.2.2 Gescheiden opvang feces en urine $\quad 21$

5.2.3 Korte verblijftijd drijfmest in stal 21

$\begin{array}{ll}5.2 .4 \text { Vergisting } & 21\end{array}$

5.2.5 Opslag digestaat $\quad 21$

$\begin{array}{ll}5.2 .6 \text { Mestscheiding } & 22\end{array}$

$\begin{array}{llr}6 & \text { Vaste mest } & 23\end{array}$

$\begin{array}{lll}6.1 & \text { Inleiding, doelstelling } & 23\end{array}$

$\begin{array}{lll}6.2 & \text { Resultaat } & 23\end{array}$

6.2.1 Melkvee $\quad 23$

6.2.2 Varkens 23

6.2.3 Pluimvee 23

6.2.4 Opslag van vaste mest (incl. dikke fractie na mestscheiding) 24

$\begin{array}{lll}6.3 & \text { Discussie / conclusie } & 24\end{array}$

$7 \quad$ Implementatie in Klimaatlat $\quad 25$

$8 \quad$ Schematisch weergave bevindingen en aanbevelingen $\quad 27$

$\begin{array}{ll}\text { Literatuur } & 29\end{array}$

Bijlage 1 Definitieve Klimaatmaatregelen MDV 32 


\section{Samenvatting}

Vooruitlopend op mogelijk beleid, gebaseerd op de EU-richtlijn voor luchtkwaliteitseisen en klimaatbeleid, is het gewenst om broeikasgasemissies uit de Nederlandse veehouderij te reduceren. Het ontwikkelen van een certificeerbare aanpak waarmee de bouw van stallen met emissiereducerende maatregelen kan worden gestimuleerd, kan daar een bijdrage aan leveren. Naar aanleiding van eerder uitgevoerd literatuuronderzoek zijn zes deelprojecten geformuleerd die nog nodig waren om van een theoretische benadering te komen tot beoordelingscriteria voor emissiereducerende maatregelen. Hierbij speelden vooral onduidelijkheden over relaties tussen methaan $\left(\mathrm{CH}_{4}\right)$-, lachgas $\left(\mathrm{N}_{2} \mathrm{O}\right)$ - en ammoniak $\left(\mathrm{NH}_{3}\right)$-emissies tijdens diverse processen of opslagomstandigheden een belangrijke rol.

Op grond van deze rapportage kunnen potentiële maatregelen beoordeeld worden en wordt een definitieve versie, in de vorm van een Klimaatlat als onderdeel van de Maatlat Duurzame Veehouderij (MDV), gepubliceerd en in gebruik genomen. De Klimaatlat bestaat uit een puntensysteem voor (stal)maatregelen ten aanzien van reductie van broeikasgassen (koolstofdioxide $\left(\mathrm{CO}_{2}\right)$ afkomstig van fossiele energiebronnen, methaan $\left(\mathrm{CH}_{4}\right)$ en lachgas $\left(\mathrm{N}_{2} \mathrm{O}\right)$ ) en heeft betrekking op rundvee, varkens en pluimvee. De Klimaatlat wordt zoveel mogelijk generiek uitgewerkt zodat de maatregelen, indien van toepassing, ook bij de overige diercategorieën kunnen worden opgenomen. Door voort te bouwen op de MDV-systematiek, met de daaraan gekoppelde fiscale regelingen, is het mogelijk om maatregelen om broeikasgasemissies te reduceren in nieuw te bouwen stallen te stimuleren.

\section{Drijfmestsystemen}

Deelproject I bestond uit een deskundigenbijeenkomst over maatregelen voor drijfmestsystemen om broeikasgasemissies te reduceren. Het doel van deze workshop was om randvoorwaarden te formuleren voor een deel van de maatregelen. Voor een aantal andere maatregelen lopen er vanuit de klimaatenvelop nog projecten, waarvoor volgend jaar meer informatie beschikbaar komt.

De conclusies waren:

Voor drijfmestsystemen dient de mest zo snel mogelijk verwijderd te worden uit de dierverblijven en daarna of emissiearm opgeslagen, of verwerkt te worden.

De overwegingen en randvoorwaarden die tijdens de workshop zijn benoemd, leiden tot een aantal aanpassingen in de formulering van de concept maatregelen. Deze conceptmaatregelen zijn meegenomen in deelproject VI en opgenomen in de Klimaatlat van de MDV.

\section{Mestmixen}

In deelproject II zou worden gekeken naar het effect van bellenmixen. Dit deelproject sluit echter aan op nog lopend onderzoek op Dairy Campus naar de effecten van mestmixen met luchtbellen op broeikasgasemissies $\left(\mathrm{CH}_{4}\right.$ en $\left.\mathrm{N}_{2} \mathrm{O}\right)$. Resultaten daarvan worden pas midden 2020 verwacht en daarom is dit deelproject nog niet uitgevoerd.

\section{Niet te stimuleren maatregelen}

Doel van deelproject III was om te komen tot een lijst met maatregelen die niet gestimuleerd moeten worden omdat ze risico's bevatten met betrekking tot bepaalde emissies.

$\mathrm{Bij}$ toepassing van droge mest in ligboxen is risico op $\mathrm{N}_{2} \mathrm{O}$-emissie. Dit kan voorkomen worden door goed management, maar een goede definitie van managementmaatregelen en ondersteunende meetresultaten ontbreken. Borging is dan ook niet haalbaar.

Bij toepassing van (open) mestverwerkingssytemen (mestscheiding) bestaat qua broeikasgassen vooral risico op $\mathrm{N}_{2} \mathrm{O}$-emissie uit de opslag van de dikke fractie. Afdekken van deze opslag kan helpen om deze emissie laag te houden en helpt tegelijkertijd, doordat de temperatuur laag gehouden wordt, om andere emissies $\left(\mathrm{CH}_{4}\right.$ en $\left.\mathrm{NH}_{3}\right)$ laag te houden.

Bij toepassing van potstallen, in het bijzonder bij diepe potstallen voor rundvee, maar ook bij varkens, zal onderin een anaerobe zone ontstaan met emissie van $\mathrm{CH}_{4}$ tot gevolg. Bij varkens zal daarnaast, door een combinatie van aerobe bovenlaag en anaerobe onderlaag, ook emissie van $\mathrm{N}_{2} \mathrm{O}$ optreden. 
Bij toepassing van vrijloopstallen met een composterende bodem zijn risico's op grote $\mathrm{N}$ verliezen, waaronder $\mathrm{N}_{2} \mathrm{O}$. Daarnaast kan $\mathrm{CH}_{4}$-emissie optreden als er anaerobe zones ontstaan. Optimalisatie van de beluchting en management om anaerobe plekken te voorkomen kunnen de emissies van broeikasgassen bij vrijloopstallen met een bodem van composterende houtsnippers mogelijk verminderen. Nader onderzoek om dit goed te kwantificeren is echter nog nodig en zal moeten uitwijzen of monitoring en borging van technische of managementmaatregelen haalbaar is. Bij compostering in het algemeen treden grote $\mathrm{N}$ verliezen (waaronder $\mathrm{N}_{2} \mathrm{O}$ ) op door aerobe afbraakprocessen. Door het ontstaan van anaerobe zones kan ook $\mathrm{CH}_{4}$-emissie optreden. Risico's op broeikasgasemissies zijn het grootst bij passieve compostering. Bij actieve compostering in gesloten systemen met luchtwassing zijn emissie mogelijk gering. Monitoring van composteringsprocessen op boerderijniveau is theoretisch mogelijk (temperatuur, gasconcentraties), maar in de praktijk niet haalbaar.

Bij beluchting van dunne fractie, om nitrificatie te stimuleren, gevolgd door een anaerobe fase om denitrificatie te stimuleren wordt primair toegepast om $\mathrm{N}$ overschotten weg te werken door omzetting van aanwezige stikstofverbindingen naar het onschadelijke $\mathrm{N}_{2}$, maar hierbij komt ook $\mathrm{N}_{2} \mathrm{O}$ vrij. Aanpassingen in het proces, waaronder cyclische beluchtingsschema's kunnen de $\mathrm{N}_{2} \mathrm{O}$-emissie beperken, maar zeker niet uitsluiten. Naast de gevolgen voor emissies is het ook de vraag in hoeverre deze maatregel gestimuleerd / benut zou moeten worden als aan de andere kant industriële $\mathrm{N}$ fixatie nodig is om kunstmest te maken. Voor de industriële $\mathrm{N}$ fixatie is namelijk (fossiele) energie nodig die ook weer leidt tot broeikasgasemissies.

\section{Effecten in de mestketen}

Doel van deelproject IV was het identificeren van kennisleemtes in de mestketen en het formuleren van vervolgstappen om deze kennisleemtes ingevuld te krijgen. Dit ter voorkoming van het verplaatsten van emissierisico's, bijvoorbeeld van stal naar opslag. Hierbij is uitgegaan van drijfmest (rundvee en varkens) als basismateriaal, waarbij emissies vanuit de mest in de stal, tijdens eventuele bewerking en in de opslag beschouwd zijn. Emissies uit de stal en de mestopslag (buiten de stal) moeten meegenomen worden omdat anders verplaatsing van emissies niet inzichtelijk gemaakt kan worden. Hiervoor is onderzoek naar broeikasgasemissie uit opslagen noodzakelijk, aangezien diverse kennisleemtes geïdentificeerd zijn. Deze zijn:

- Gegevens over broeikasgasemissies uit (langdurige) drijfmestopslag (in de stal of daarbuiten) na maatregelen zoals koelen, zouten en beluchten zijn zeer beperkt of niet beschikbaar. Hoe lang houden de gunstige (emissieremmende) omstandigheden stand of moet de behandeling voortgezet / herhaald worden? Ook gegevens over emissies bij toediening van behandelde mest zijn niet bekend.

- Gegevens over broeikasgasemissies bij gescheiden opvang zijn zeer beperkt of niet beschikbaar en zijn mogelijk sterk afhankelijk van gekozen systeem en management (hoeveelheid strooisel in stal). Onderzoek en ontwikkeling heeft zich vooral gericht op emissie van $\mathrm{NH}_{3}$ vanuit de stal. De grootste emissies treden echter op tijdens de opslag en toediening van de (dunne en) dikke fractie. Hier is echter geen onderzoek naar bekend.

- Gegevens over broeikasgasemissies uit opslag van digestaat zijn zeer beperkt en niet eenduidig.

- Gegevens over broeikasgasemissies uit opslag van dikke en dunne fracties na mestscheiding, al dan niet na vergisting, zijn zeer beperkt en niet eenduidig. Ook gegevens over invloed van gebruikte scheidingstechniek op broeikasgasemissies zijn niet beschikbaar.

Vaste mest

Doel van deelproject IV was te inventariseren welke emissies uit verschillende opslagsystemen voor vaste mest plaats vinden en welke kennis nodig is om maatregelen te formuleren om deze emissies te voorkomen. Vaste mest heeft betrekking op pluimveemest, zowel strooiselmest als (gedroogde) bandmest, mest uit strohuisvesting voor o.a. varkens en rundvee en de dikke fractie na mestscheiding van varkens- en rundveemest. Uit vaste mest kunnen, afhankelijk van de omstandigheden en gebruikte technieken, $\mathrm{CH}_{4}, \mathrm{~N}_{2} \mathrm{O}$ en $\mathrm{NH}_{3}$ emitteren. In het algemeen kan gesteld worden dat effecten van maatregelen bij vaste mest moeilijker zijn in te schatten dan bij drijfmest, mede omdat weinig (kwantitatieve) onderzoeksgegevens beschikbaar zijn. Ook effecten van maatregelen in de ene fase op emissies in volgende fases zijn niet of slechts zeer beperkt bekend. Aanvullend onderzoek, zowel op 
het gebied van metingen als modelontwikkeling, is hier gewenst, waarbij ook effecten bij uitrijden meegenomen moeten worden.

Enkele specifieke kennishiaten met betrekking tot pluimveemest zijn:

- $\quad$ Er zijn nog geen meetresultaten voor broeikasgassen beschikbaar van systemen met vloerkoeling voor strooiselmest, hoewel dit wel een methode is die potentie heeft.

- $\quad$ Er zijn nog geen meetresultaten voor broeikasgassen beschikbaar van systemen met extra stalrecirculatie van lucht. Effecten op $\mathrm{N}_{2} \mathrm{O}$-emissie zouden mogelijk nadelig kunnen zijn als een anaerobe onderlaag gecombineerd wordt met een door droging meer aerobe bovenlaag. Een effectieve strategie voor pluimvee is het frequent afvoeren van mest uit de stal (meerdere keren per dag) en snel drogen tot $>80 \%$ droge stof. Voor mest met een droge stofgehalte van boven de $80 \%$ geldt dat deze zonder veel emissie van $\mathrm{NH}_{3}, \mathrm{~N}_{2} \mathrm{O}$ en $\mathrm{CH}_{4}$ opgeslagen kan worden, aangezien microbiële processen nagenoeg stil liggen

Vaste mest met lagere droge stof gehaltes, al dan niet met strooisel, maar waar nog wel sprake is van een rul product, zal bij opslag gaan broeien, oftewel passief composteren, met daarbij behorende emissies van $\mathrm{NH}_{3}, \mathrm{~N}_{2} \mathrm{O}$ en $\mathrm{CH}_{4}$. De enige maatregel die hier zinvol lijkt is het afdekken van de mestopslag doordat daarmee het op gang komen van het composteringsproces, en de daarmee gepaard gaande temperatuurtoename, voorkomen kan worden.

Dikke fractie na scheiding in de vorm van een koek (zeefbanden) zal minder en in de vorm van drab (zeefbocht, trilzeef) zal (bijna) geen $\mathrm{N}_{2} \mathrm{O}$-emissie voortbrengen gezien de meer anaerobe omstandigheden. Emissie van $\mathrm{CH}_{4}$ kan hierdoor wel toenemen.

\section{Implementatie in Klimaatlat}

Voor implementatie in de Klimaatlat (Deelproject VI) is slechts en beperkt aantal maatregelen praktijkrijp. Door het opnemen van deze maatregelen wordt echter de bewustwording en verdere ontwikkeling van maatregelen gestimuleerd. De nu opgenomen maatregelen beperken zich tot drijfmestsystemen, waarbij snelle verwijdering van mest uit het dierverblijf gekoppeld wordt aan emissiearme opslag of mestverwerking. 


\section{$1 \quad$ Inleiding}

Vooruitlopend op mogelijk beleid, zoals de EU-richtlijn voor luchtkwaliteitseisen en klimaatbeleid, is het gewenst om een certificeerbare aanpak te ontwikkelen, waarmee de reductie van broeikasgasemissies uit de Nederlandse veehouderij via de bouw van stallen met op emissiereductie gerichte maatregelen kan worden gestimuleerd.

SMK heeft een literatuuronderzoek laten uitvoeren door CLM naar maatregelen die in stallen uitgevoerd kunnen worden om broeikasgasemissies te reduceren [1]. De uitkomsten van dit literatuuronderzoek zijn besproken met diverse deskundigen en hebben geleid tot een concept lijst met best practices (zie Tabel 1.1). Er waren echter nog onduidelijkheden over de verbindingen tussen $\mathrm{CH}_{4}$ - en $\mathrm{N}_{2} \mathrm{O}$-emissies met bijvoorbeeld composteren, $\mathrm{NH}_{3}$ en stikstofverliezen. Verder stonden er nog vragen open over de manier waarop maatregelen precies moeten worden uitgevoerd om tot de verwachtte emissiereductie te komen. Dit rapport bevat het verslag van een aantal deelprojecten die uitgevoerd zijn door WUR in samenwerking met SMK om de nog openstaande vragen te beantwoorden. Op grond hiervan kunnen potentiële maatregelen beoordeeld worden en kan een definitieve versie, in de vorm van een Klimaatlat als onderdeel van de Maatlat Duurzame Veehouderij (MDV), worden gepubliceerd en in gebruik genomen.

Tabel 1.1 Concept lijst best pratices op basis van eerder uitgevoerd literatuuronderzoek.

\begin{tabular}{ll} 
Nummer & Omschrijving \\
\hline 1 & Kortere verblijftijd drijfmest in stalsysteem (dierverblijf) \\
\hline 2 & Verlagen opslagcapaciteit mestkelder in dierverblijf/verplaatsen mestopslag naar buiten het dierverblijf \\
\hline 3 & Mestvergistingsinstallatie \\
\hline 5 & Verdunnen van mest \\
\hline 7 & Mest mixen met luchtbellen \\
\hline 8 & Koelen van mest met koeldeksysteem \\
\hline 9 & Ganzuren van mest \\
\hline
\end{tabular}

De Klimaatlat zal bestaan uit een puntensysteem voor (stal)maatregelen ten aanzien van reductie van broeikasgassen (koolstofdioxide $\left(\mathrm{CO}_{2}\right)$, methaan $\left(\mathrm{CH}_{4}\right)$ en lachgas $\left(\mathrm{N}_{2} \mathrm{O}\right)$ ) en betrekking hebben op rundvee, varkens en pluimvee. De Klimaatlat wordt zoveel mogelijk generiek uitgewerkt zodat de maatregelen, indien van toepassing, ook bij de overige diercategorieën kunnen worden opgenomen.

De inhoud van de Klimaatlat zal aansluiten op de MDV, waarin onder andere al maatregelen zijn opgenomen die gaan over energiebesparing en opwekking van duurzame energie, ter voorkoming van $\mathrm{CO}_{2}$-uitstoot. Doel is de MDV in 2020 te verbreden met maatregelen die de uitstoot van de zgn. overige broeikasgassen, $\mathrm{CH}_{4}$ en $\mathrm{N}_{2} \mathrm{O}$ reduceren. Door voort te bouwen op de MDV-systematiek, met de daaraan gekoppelde fiscale regelingen, is het mogelijk om maatregelen om broeikasgasemissies te reduceren in nieuw te bouwen stallen te stimuleren. Via de MDV wordt circa $30 \%$ (soms ook meer) van de nieuw te bouwen stallen in de regeling betrokken.

Met het uitwerken van een Klimaatlat met criteria en ambitienormen voor MDV-certificering, wordt het mogelijk om broeikasgasemissies integraal onderdeel te laten worden bij het verduurzamen van nieuw te bouwen stallen. Verder kan de Klimaatlat, naast certificatie, ook breder toegepast worden.

Bijvoorbeeld, biedt het een praktische mogelijkheid om de losse onderdelen van het certificaat te monitoren (aansluitend op de monitoringsbehoefte vanuit de Monitor Integraal Duurzame Stallen). De Klimaatlat wordt daartoe ontwikkeld als benchmark lijst van best practices. 
Doel van dit onderzoek was de eerder genoemde openstaande vragen ten aanzien van broeikasgassen te beantwoorden alsmede de relatie met $\mathrm{NH}_{3}$ te beschrijven. Daarnaast is gedocumenteerd hoe de maatregelen moeten worden uitgevoerd om het gewenste resultaat te bereiken.

Op basis van de resultaten uit deelprojecten I t/m V (hoofdstukken $2 \mathrm{t} / \mathrm{m} 6$ ) is besloten welke maatregelen van de concept lijst met maatregelen (in Tabel 1.1), worden opgenomen in een shortlist. In deelproject VI (hoofdstuk 7) is de implementatie in de Klimaatlat beschreven. Tot slot zijn op basis van de resultaten van de deelprojecten conclusies opgesteld (hoofdstuk 8 ). 


\section{Drijfmestsystemen}

Deelproject I bestond uit een deskundigenbijeenkomst over maatregelen voor drijfmestsystemen om broeikasgasemissies te reduceren. Het doel van deze workshop was om randvoorwaarden te formuleren voor een deel van de maatregelen (maatregel 1, 2, 4, 5, 6 en 7 uit Tabel 1.1). Voor een aantal andere maatregelen lopen er vanuit de klimaatenvelop nog projecten, waarvoor volgend jaar meer informatie beschikbaar komt.

Aandachtspunt is de wisselwerking met andere thema's (bijvoorbeeld $\mathrm{NH}_{3}$ en $\mathrm{CH}_{4}$ ) en afwentelingen in de keten (stal, opslag, verwerking en toediening). Waar moeten we rekening mee houden? Voorkomen moet worden om een reductie in de stal te realiseren, terwijl er negatieve gevolgen zijn voor de naliggende schakels. Deze kritieke punten willen we graag benoemen. Deze punten zijn besproken per maatregel en hieronder uitgewerkt.

\subsection{Maatregel korte verblijftijd drijfmest in stalsysteem}

\section{Overwegingen:}

- $\quad$ Dit is geen op zichzelf staande maatregel. Snel verwijderen van de mest uit de stal is wel een randvoorwaarde om verdere bewerkingen of emissiearme mestopslag te kunnen realiseren.

- De ingeschatte $\mathrm{CH}_{4}$-emissiereductie van $50-86 \%$ is realistisch voor alle soorten drijfmest (varkens en rundvee), maar alleen in combinatie met een emissiearme mestopslag of mestverwerking.

- Onderscheidend is de verblijftijd van de mest in de stal. Hoe frequenter de mest wordt verwijderd hoe beter. Bij varkens wordt voorgesteld om een onderscheid te maken tussen:

- Tenminste een keer per dag afvoeren,

- Tenminste een keer per week afvoeren,

- Tenminste eenmaal per maand afvoeren.

- $\quad$ Bij melkvee is een dichte vloer gewenst, waarbij de mest van de vloer wordt verwijderd naar een afstortpunt aan het einde van de loopgang. De mest dient uit het afstortpunt verwijderd te worden, hiervoor kunnen dezelfde termijnen worden aangehouden als eerder voor varkensdrijfmest is aangegeven. Daarna moet de mest overgebracht worden naar een emissiearme mestopslag of mestverwerkingsinstallatie.

- De $\mathrm{CH}_{4}$-emissie van de loopvloer in melkveestallen is beperkt, dus de techniek waarmee de mest van de vloer wordt verwijderd (mestschuif of mestrobot) maakt niet uit. Focus moet uitgaan naar het verwijderen van de mest uit de opslag in het dierverblijf. Let hierbij op de beschrijving van mestopslag onder de vloer (zoals bij een roostervloer), of onder de stal (volledig afgesloten van het dierverblijf). Bij sommige grondsoorten, of met beperkte ruimte op het bouwblok, is het logisch om de mestopslag onder de stal te realiseren en dus niet een externe mestopslag te bouwen.

- Aandachtspunt bij dichte vloeren bij melkvee is de beloopbaarheid van de vloer. Dit kan geborgd worden door de vloer nat te houden, voldoende profilering of rubber op de vloer.

- $\quad$ Bij varkens is een de dichte vloer geen optie omdat het niet praktisch is vanwege de hokindeling en het feit dat de varkens op de vloer liggen.

- Als referentiekader wordt voorgesteld om uit te gaan van diepe kelders en luchtwasser in varkensstallen, en een roostervloer met mestkelder eronder in melkveestallen.

- Voor de (punt)waardering van de emissiereductie kan het beste worden uitgegaan van de $\mathrm{CH}_{4}$-emissie uit de mest. Voor de enterische emissie zijn nog onvoldoende technische aspecten bekend.

- Als de mest en urine direct worden gescheiden, dan levert de maatregel ook $\mathrm{NH}_{3}-$ emissiereductie op en een beter stalklimaat.

- Ook in de genoemde systemen van de Rav-lijst zit management. Uitgegaan wordt dat dit gehandhaafd wordt door de overheid, maar daar zijn kanttekeningen bij te plaatsen. Geadviseerd wordt om de leafletbeschrijvingen van de Rav nog eens kritisch te lezen vanuit $\mathrm{CH}_{4}$ oogpunt. Hoe aannemelijk is het dat de mest volgens een bepaalde frequentie wordt verwijderd uit de stal? (Bij mestband en mestpannen weet je zeker dat de mest direct wordt 
verwijderd. Maar bij schuine putwanden kan er dagelijks of eenmaal per twee weken worden afgevoerd. Alleen als er sprake is van mestscheiding, waarbij de dunne fractie wordt gebruikt om te spoelen garandeert een frequente verwijdering. Dit betreft echter voornamelijk management.)

- Hoe schoner de put is hoe minder snel het proces van $\mathrm{CH}_{4}$-vorming op gang komt. Een mestschuif onder de vloer bij vleeskalveren is een goed voorbeeld.

- Na de snelle verwijdering van de mest uit het dierverblijf:

- moeten de $\mathrm{CH}_{4}$-vormende organismen zoveel mogelijk geremd worden, dit kan door de mest te koelen, aan te zuren of te verzouten, of

- moet het $\mathrm{CH}_{4}$-vormingsproces plaatsvinden onder gecontroleerde omstandigheden, in een mestvergister.

Opgemerkt wordt dat aanzuren en verzouten ongewenst zijn in verband met zwavelzuur c.q. verzilting van landbouwgrond.

- Bij mestopslagen is meestal sprake van luchtdichte opslag (in relatie tot $\mathrm{NH}_{3}$-emissie), maar voor $\mathrm{CH}_{4}$ is een gasdichte opslag nodig. Hierbij dienen de nodige veiligheidsvoorzieningen te worden getroffen. Een gasdichte mestopslag onder de stal is wellicht niet wenselijk vanwege veiligheidsrisico's. Geadviseerd wordt om bij enkele specialisten navraag te doen over de mogelijkheden rondom gasdichte mestopslagen.

- Op de Milieulijst is een gasdichte kap voor de mestopslag opgenomen (code B2208). Let daarbij op de definitie van 'nuttige' toepassing van de afgevangen gassen. Uit berekeningen blijkt dat het affakkelen van afgevangen gassen uit mestopslagen maar een beperkt broeikasgaseffect ( 1 a $2 \%$ verschil) heeft ten opzichte van de omzetting van die afgevangen gassen naar energie. Dit is een argument om affakkelen niet uit te sluiten.

- De genoemde maatregelen zijn lastig te realiseren bij het verbouwen van stallen.

\subsection{Maatregel mestvergistingsinstallatie}

- Er worden soms kanttekeningen geplaatst bij het vergisten van rundveemest, omdat de organische stof in de bodem dan langzamer wordt afgebroken. Echter, de aanwezige deskundigen stellen dat een snelle verwerking van dagverse mest relevant is, niet de diersoort. De mest van beide diersoorten bevat namelijk organische stof.

- Voor maximale $\mathrm{CH}_{4}$-emissiereductie is het wenselijk dat de mest uit de stal direct de vergister ingaat. In de varkenshouderij wordt vaker in groepsverband mest vergist, maar in dat geval is een varkenshouder afhankelijk van de mestafvoer naar de regionale mestvergister. Hier zou een maximaal aantal dagen moeten gelden dat de mest op het varkensbedrijf blijft, voordat het naar de mestvergister gaat. Overigens vallen de mestafvoer en vergister op een andere locatie buiten de scope van de MDV.

- De deskundigen gaan uit van monovergisting, met $100 \%$ mest input. De vraag is of costromen die op het erf vrijkomen ook toegestaan worden om mee te vergisten. De afkomst van de co-producten is in de MDV echter niet te borgen.

- Er dient onderhoud aan de mestvergister plaats te vinden, zodat op lekkages wordt gecontroleerd en deze opgelost kunnen worden. Overigens wil een eigenaar vanuit economisch oogpunt ook geen lekkages hebben, omdat dit een groot effect heeft op de opbrengsten van de mestvergister.

- De vergister zelf is een vorm van tijdelijke mestopslag, maar daarnaast moeten voorwaarden gesteld worden aan de opslag van de producten die uit de mestvergister komen (digestaat). De eindproducten dienen namelijk ook emissiearm opgeslagen te worden. Hiervoor moet de opslag van digestaat in een gasdichte opslag plaatsvinden, of moet digestaat gehygiëniseerd worden door aan te zuren of andere conserveringsmiddelen (bijv. zouten) te gebruiken.

- In de NTA 9766 zijn veiligheidsvoorschriften opgenomen voor de eindopslag. Deze wordt algemeen toegepast; ook in de omgevingsvergunning wordt verwezen naar de NTA 9766.

- Let op hoe met de afgevangen gassen wordt omgegaan. Dit kan door een WKK toepassing, het opwaarderen van groen gas, een ketel op biogas of affakkelen.

- Bij mestvergisting is afwenteling een aandachtspunt. Dit kan in de vorm van $\mathrm{N}_{2} \mathrm{O}$-emissies en emissie bij de toediening van de eindproducten. Naar de verliezen bij toediening is nog weinig onderzoek gedaan. 


\subsection{Verdunnen van de mest}

- Verdunnen is vooral een $\mathrm{NH}_{3}$-emissiereducerende maatregel. $\mathrm{Er}$ is in een onderzoek zijdelings een effect op reductie in $\mathrm{CH}_{4}$-emissie geconstateerd, maar er is meer bewijs nodig om het werkingsprincipe voor $\mathrm{CH}_{4}$-emissiereductie te onderbouwen.

- Deze maatregel kan wel zorgen dat de mest sneller uit de stal wordt verwijderd en kan als zodanig aan de eerste maatregel worden toegevoegd.

- Het spoelgotensysteem kan de mest meerdere keren per dag uit de stal verwijderen. Verdunnen is hierbij een voorwaarde.

- Bij mestopvang in een ammoniakarme vloeistof of water, is de mest-waterverhouding van belang. Let ook op de capaciteit van de mestopslag.

- Een rioleringssysteem geeft geen garantie dat de mest sneller wordt afgevoerd. Deze wordt niet meegenomen onder versneld verwijderen van de mest uit de stal.

- In dit systeem wordt de mest in een dunne en dikke fractie gescheiden. De dunne fractie wordt stikstofarm gemaakt en daarna gebruikt om te spoelen. Op deze manier wordt de mest snel verwijderd uit de stal. In principe zijn ook andere spoelvloeistoffen mogelijk maar, omdat water kostenverhogend is voor de mestafzet, wordt de dunne fractie gebruikt.

- Aandachtspunt bij de mestscheiding is de dubbele opslag. Bij mestscheiding emitteren beide fracties verschillend. Door scheiding blijft er minder dunne (vloeibare) fractie over, waar $\mathrm{CH}_{4}$ emissie aandachtspunt is. Uit de dikke (stapelbare) fractie emitteert minder $\mathrm{CH}_{4}$, omdat de condities daarvoor slechter zijn, maar daarentegen is $\mathrm{N}_{2} \mathrm{O}$-emissie een aandachtspunt.

\subsection{Koeldeksysteem / mestkoeling}

- $\quad$ Er loopt een praktijkproef in Groningen in een melkveestal met koeling in de mestkelder. De resultaten hiervan worden in 2020 verwacht.

- Het koeldeksysteem koelt de toplaag van de mest in de opslag. Ervan uitgaande dat de koude mest naar beneden zakt, zullen er geen koude/warme zones ontstaan, maar is er sprake van egale koeling. Als een systeem de wanden zou koelen, dan dient de mest gemixt te worden om een egale koeling te verkrijgen. Opgemerkt wordt dat de resultaten van praktijkproef in Groningen waarschijnlijk aangeven of mixen werkelijk nodig, of dat warmtetransport in de mest zelf (geleiding) voldoende is.

- Uit de praktijk is bekend dat een koeldeksysteem, waarbij grondwater van 10-11 graden wordt gebruikt om te koelen, een mesttemperatuur van 14 graden realiseert.

- Het effect van de mestkoeling is afhankelijk van de temperatuur die wordt bereikt. Het effect is niet lineair (maar een log-functie), maar binnen de bandbreedte van 5-15 graden is het effect wel lineair te beoordelen. De $\mathrm{CH}_{4}$-vorming komt volledig tot stilstand bij 5 graden, ook bij 10 graden is er effect, boven de 15 graden is het effect op het $\mathrm{CH}_{4}$-vormingsproces beperkt. Een lagere temperatuur zou dus meer punten moeten krijgen. Bij varkens is het effect van de relatieve reductie groter dan bij melkvee, dit zou ook in de punten tot uiting moeten komen.

- Let op dat het gaat om systemen die als hoofddoel mestkoeling moeten hebben. Het is in het kader van $\mathrm{CH}_{4}$-emissie niet de bedoeling om de mest als warmte-koude-opslag te gebruiken.

- Mestpankoeling bij kraamzeugen zou ook gewaardeerd kunnen worden. Bij kraamzeugen worden de gekoelde mestpannen eens in de 5 weken geleegd, waarbij er dus een effect is op de mest die in de gekoelde mestpan wordt opgevangen. De overige mestpansystemen hebben geen effect op $\mathrm{CH}_{4}$ vanuit de koeling, omdat deze alleen bedoeld zijn voor een versnelde afvoer van de mest uit de dierverblijven, en niet dienst doen als een gekoelde mestopslag.

- Perspectiefvolle maatregel voor opslagen van drijfmest. Meest effectief is de mest snel te koelen en daarna in een geïsoleerde mestopslag op te slaan. De temperatuur zou gemonitord moeten worden zodat de grenswaarden van 5 of 10 graden gewaarborgd blijven. Luchtdicht/gasdicht maakt dan niet uit, omdat het $\mathrm{CH}_{4}$-vormingsproces wordt verstoord.

- $\quad$ Bij pluimvee zou vloerkoeling ook moeten werken tegen $\mathrm{CH}_{4}$-vorming, maar bij pluimvee is de $\mathrm{CH}_{4}$-vorming beperkt. Daar is $\mathrm{N}_{2} \mathrm{O}$ een belangrijker broeikasgas. 


\subsection{Aanzuren van mest}

- Zwavelzuur is niet wenselijk als middel om de mest aan te zuren. Zwavel is een corrosieve stof die bij het toedienen van de mest voor te hoge waardes van zwavel in de bodem kan zorgen. Daarnaast is het een dure maatregel. Er is $50 \mathrm{~kg}$ kalk per hectare nodig om het zwavelzuur te neutraliseren en geur is een issue bij het toedienen van met zwavel aangezuurde mest. Ook gelden er wettelijke beperkingen aan de capaciteit van de opslag van zwavelzuur op het bedrijf (dit moet in de vergunning zijn opgenomen). Tot slot is bij grootschalige toepassing er ook niet voldoende zwavel beschikbaar als grondstof voor zwavelzuur.

- In Denemarken zijn er systemen operationeel die spoelen met een aangezuurde dunne fractie. Dit valt echter onder een snelle verwijdering van mest uit de dierverblijven. De in de bespreeknotitie genoemde Rav systemen, die met aangezuurde vloeistof spoelen om de mest elke week uit het dierverblijf af te voeren, kunnen daarom in maatregel 1 worden opgenomen. 
- $\quad$ Om de $\mathrm{CH}_{4}$-emissie in de mestopslag te remmen dient de $\mathrm{pH}$ waarde niet boven de 5,5 uit te komen. Eenmalig aanzuren bij de afvoer uit het dierverblijf is onvoldoende om het $\mathrm{CH}_{4}$ vormingsproces op langere termijn te remmen. Voorkomen moet worden dat de $\mathrm{pH}$-waarde in de opslag omhoog gaat. Uit onderzoek blijkt dat er in runderdrijfmest $70 \%$ reductie van de $\mathrm{CH}_{4}$-emissie is gemeten [2].

- Methaan en $\mathrm{NH}_{3}$ reageren verschillend op het verlagen van de $\mathrm{pH}$-waarde van de mest. Voor $\mathrm{CH}_{4}$ en $\mathrm{N}_{2} \mathrm{O}$ geldt een optimum van respectievelijk 7 en 6 qua vormingsproces, terwijl de $\mathrm{NH}_{3}-$ vorming exponentieel stijgt bij een hogere $\mathrm{pH}$ waarde. De methanogene activiteit is laag bij een $\mathrm{pH}$-waarde van 5,5 of lager.

- Een alternatief voor zwavelzuur is de mest biologisch of organisch aan te zuren. In de Rav leaflets staan de volgende organsiche zuren genoemd:

- Calprona (dit is een mengsel van zuivere zuren);

- MMDBA (mixed mono and dibasic acids); of

- AMGUARD (dit is een mengsel van diverse zuren).

- $\quad$ Er zijn verschillende conserveringsmiddelen die helpen om de $\mathrm{CH}_{4}$-vorming te remmen: zuren en zouten. Echter, verzouten is ongewenst in verband met de verzilting van landbouwgronden.

- Aan de opslag van de aangezuurde mest dienen randvoorwaarden te worden gesteld. De pHwaarde in de mestopslag moet gemonitord worden. Verder gelden dezelfde randvoorwaarden als bij de eerder besproken naopslag van digestaat uit de vergister.

\subsection{Conclusie}

Voor drijfmestsystemen dient de mest zo snel mogelijk verwijderd te worden uit de dierverblijven en daarna of emissiearm opgeslagen, of verwerkt te worden.

De overwegingen en randvoorwaarden die tijdens de workshop zijn benoemd, leiden tot een aantal aanpassingen in de formulering van de concept maatregelen. Deze zijn meegenomen in deelproject VI en de uiteindelijke uitwerking van de nieuwe Klimaatlat (Bijlage 1). 


\section{Mestmixen}

In deelproject II zou worden gekeken naar het effect van bellenmixen en verwijderen van verdunde mest uit de stal (mestmixen met luchtbellen). Dit deelproject sluit echter aan op nog lopend onderzoek op Dairy Campus naar de effecten van mestmixen met luchtbellen. Dit onderzoek is primair gericht op $\mathrm{NH}_{3}$. Het lijkt erop dat mestmixen met luchtbellen weinig perspectief heeft voor de reductie van $\mathrm{NH}_{3}$-emissies [3]. Kleinschalig onderzoek met varkensmest [4] toont echter aan dat een reductie van $\mathrm{CH}_{4}$-emissies mogelijk is. Daarnaast dient $\mathrm{N}_{2} \mathrm{O}$ ook meegenomen te worden omdat er een risico is op afwenteling.

Doelstelling is om inzicht te krijgen in de effecten van mestmixen met luchtbellen op de verschillende broeikasgasemissies en hoe deze maatregel moet worden uitgevoerd om tot de verwachte reducties te komen. Om de maatregelen voor beluchten en verwijderen verdunde mest correct toe te passen is eigenlijk aanvullend onderzoek nodig. Het onderzoek bij de Dairy Campus levert namelijk één type instelling voor gebruik op, maar geen kennis van de bandbreedtes (zoals minimale en maximale beluchtingsinstellingen). Deze resultaten bieden echter wel perspectief om bellenmixen al dan niet als $\mathrm{CH}_{4}$-reducerende maatregel toe te passen.

Doordat het onderzoek op Dairy Campus nog in uitvoering is en de resultaten pas midden 2020 verwacht worden, is dit deelproject nog niet uitgevoerd. 


\section{$4 \quad$ Niet te stimuleren maatregelen}

\subsection{Inleiding, doelstelling}

Doel van deelproject III was om te komen tot een lijst met maatregelen die niet gestimuleerd moeten worden omdat ze risico's bevatten met betrekking tot bepaalde emissies. Een aantal maatregelen werden in het projectvoorstel al genoemd, zoals 1) droge mest in ligboxen, 2) open mestverwerkingssystemen, 3) potstallen en 4) compostering. Naast de potstallen zijn ook de vrijloopstallen in de uitwerking opgenomen en is beluchting (van dunne fracties) als extra maatregel toegevoegd.

\subsection{Resultaat}

Aan de hand van literatuurstudie en consultatie van experts is een lijst opgesteld van risicovolle maatregelen, zijn de risico's en/of knelpunten benoemd en is gekeken naar mogelijke oplossingsrichtingen (Tabel 4.1). Waar mogelijk is een advies gegeven hoe verder met deze maatregelen om te gaan.

Tabel 4.1 Lijst met risicovolle maatregelen, de risico's / knelpunten en mogelijke oplossingen en bron (zie literatuurlijst).

\begin{tabular}{|c|c|c|c|}
\hline Maatregel & Risico / knelpunt & Mogelijke oplossing & Bron \\
\hline Droge mest in ligboxen & $\mathrm{N}_{2} \mathrm{O}\left(\right.$ en $\left.\mathrm{CO}_{2}, \mathrm{NH}_{3}\right)$ emissies & Alternatief beddingmateriaal gebruiken & {$[5]$} \\
\hline $\begin{array}{l}\text { Open } \\
\text { mestverwerkingssystemen }\end{array}$ & $\begin{array}{l}\text { Tijdens verwerking (kort) vooral } \\
\mathrm{NH}_{3} \text {, opslag van dikke fractie } \\
\mathrm{N}_{2} \mathrm{O} \text { (indien rul) }\end{array}$ & $\begin{array}{l}\mathrm{NH}_{3} \text { : Mestverwerking in afgesloten loods met } \\
\text { luchtwassers } \\
\mathrm{N}_{2} \mathrm{O} \text { : afdekken opslag dikke fractie }\end{array}$ & {$[6]$} \\
\hline Potstallen & $\begin{array}{l}\mathrm{CH}_{4} \text { en } \mathrm{N}_{2} \mathrm{O} \text { emissies (vooral bij } \\
\text { diepe pot rundvee) }\end{array}$ & $\begin{array}{l}\text { Vocht afvoeren, frequent strooisel verversen, } \\
\text { (anaerobe laag voorkomen) }\end{array}$ & {$[6,7]$} \\
\hline Beluchting (dunne fractie) & $\begin{array}{l}\mathrm{N}_{2} \mathrm{O}\left(\text { en } \mathrm{NH}_{3}\right) \text { emissies en veel } \\
\mathrm{N} \text { verlies }\left(\mathrm{N}_{2}\right)\end{array}$ & $\begin{array}{l}\text { Finetunen proces of cyclische } \\
\text { beluchtingsschema's }\end{array}$ & {$[11,12]$} \\
\hline
\end{tabular}

\subsubsection{Droge mest in ligboxen}

De droge fractie, verkregen na scheiding van runderdrijfmest door middel van bijvoorbeeld een vijzelpers, bevat bij voorkeur vooral de grovere, niet-verteerde delen uit het rantsoen. Een rul product met een voldoende hoog droge stof percentage (minimaal 30\%) en een goed ligboxenmanagement zijn van belang [5].

Hoewel specifiek onderzoek naar emissies uit ligboxen met droge mest ontbreekt, moet rekening gehouden worden met stikstofverliezen door de emissie van $\mathrm{NH}_{3}, \mathrm{~N}_{2} \mathrm{O}$ en $\mathrm{N}_{2}$. Dit kan alleen voorkomen worden door goed management waardoor broei voorkomen kan worden, dat wil zeggen vers en in dunne lagen aanbrengen [5] en zorgen dat de boxen droog blijven. Een goede definitie van managementmaatregelen en ondersteunende meetresultaten ontbreken echter. Emissie van $\mathrm{CH}_{4}$ is minder waarschijnlijk.

Oplossingsrichting kan hier eigenlijk alleen gevonden worden in andere materialen als boxbedekking die minder $\mathrm{N}$ bevatten, aangezien onderbouwde randvoorwaarden voor management nog uitgewerkt moeten worden.

\subsubsection{Open mestverwerkingssystemen}

Mestscheiding vindt meestal plaats in relatief gesloten systemen en het proces van scheiden is een kortdurend proces, waardoor emissies tijdens het scheiden beperkt zullen blijven tot wat $\mathrm{NH}_{3}$. Problemen doen zich vooral voor bij de opslag van de dikke fractie, hetgeen nog vaak open gebeurt. 
Indien dit een rul product betreft is er aanzienlijke kans op $\mathrm{N}_{2} \mathrm{O}$-emissie. De dunne fractie of concentraten wordt meestal al in een gesloten opslag bewaard.

Oplossingsrichting, vooral voor $\mathrm{NH}_{3}$ emissies, kan gezocht worden in het verplicht stellen om mestscheiding in een afgesloten loods te laten plaatsvinden met luchtwassers (al een eis in de provincie Noord-Brabant).

Oplossingsrichting voor de $\mathrm{N}_{2} \mathrm{O}$ emissies moet eerder gezocht worden in eisen aan de opslag van de dikke fractie, waarbij afdekken een goede optie kan zijn. Doordat afdekken helpt om de temperatuur in de hoop laag te houden helpt dit tegelijkertijd ook om andere emissie $\left(\mathrm{NH}_{3}, \mathrm{CH}_{4}\right)$ te verminderen of laag te houden [6].

\subsubsection{Potstallen}

In potstallen, in het bijzonder bij diepe potstallen voor rundvee, maar ook bij varkens, zal onderin een anaerobe zone ontstaan waardoor emissies van $\mathrm{CH}_{4}$ flink kunnen toenemen. De $\mathrm{CH}_{4}$-emissie kan volgens Webb et al [6] tot 6 keer hoger zijn dan bij drijfmestsystemen voor melkvee en de bijdrage van $\mathrm{CH}_{4}$ aan de totale broeikasgasemissies uit een diepe potstal is volgens hen veel groter dan die van $\mathrm{N}_{2} \mathrm{O}$. Pijlman et al [7] rapporteren een 3 tot 4 keer hogere $\mathrm{CH}_{4}\left(\right.$ en $\left.\mathrm{NH}_{3}\right)$ emissie uit potstallen ten opzichte van reguliere melkveestallen op basis van gegevens van Mosquera et al [13, 14]. Er is dus consensus over een flink hogere emissie van vooral $\mathrm{CH}_{4}$ uit potstallen ten opzichte van drijfmestsystemen voor melkvee, maar een exacte factor is nog moeilijk te geven. Doordat de bovenlaag van het strooiselpakket bij varkens meer aeroob is door het wroeten wordt $\mathrm{CH}_{4}$ waarschijnlijk door methanofiele bacteriën geoxideerd waardoor $\mathrm{CH}_{4}$-emissies beperkt zullen zijn. Daarnaast zal door de combinatie van een aerobe bovenlaag en anaerobe onderlaag $\mathrm{N}_{2} \mathrm{O}$-vorming optreden en is de bijdrage van $\mathrm{N}_{2} \mathrm{O}$ aan de totale broeikasgasemissies hoger dan die van $\mathrm{CH}_{4}[6,7]$. De voorgestelde emissiefactoren voor een rondloopstal met zeugenvoerstation en strobed (RAV D1.3.10) voor guste en dragende zeugen laten echter wel een lagere $\mathrm{CH}_{4}$-emissie $(13.8 \mathrm{~kg}$ per dierplaats per jaar) en hogere $\mathrm{N}_{2} \mathrm{O}$-emissie $(0.17 \mathrm{~kg}$ per dierplaats per jaar) zien ten opzichte van drijfmestsystemen met oude mest (23.3, resp. $0.07 \mathrm{~kg}$ ) [13], maar niet dat de bijdrage van $\mathrm{N}_{2} \mathrm{O}$ aan de totale broeikasgasemissies hoger zijn dan die van $\mathrm{CH}_{4}$.

Voor geiten zijn geen metingen van $\mathrm{CH}_{4}$ - en $\mathrm{N}_{2} \mathrm{O}$-emissies bekend [7]. Metingen in het kader van de klimaatenvelop kunnen mogelijk meer duidelijkheid bieden.

\subsubsection{Vrijloopstallen}

Gebruik van compost als bodembedekking in vrijloopstallen wordt afgeraden vanuit het oogpunt van melkkwaliteit door zuivelorganisaties [8]. Daarnaast hebben deze stallen ook hoge $\mathrm{N}$-verliezen. Ook bij andere bodembedekking, zoals houtkrullen of stro zijn $\mathrm{NH}_{3}$ - en $\mathrm{N}_{2} \mathrm{O}$-emissies aandachtspunten en kunnen bij compostering (soms gestimuleerd door extra beluchting) grote $\mathrm{N}$-verliezen optreden (deels in de vorm van het onschuldige $\mathrm{N}_{2}$ ). Emissie van $\mathrm{CH}_{4}$ is bij vrijloopstallen met een composterende bodem van houtsnippers theoretisch geen probleem als anaerobe zones helemaal zouden ontbreken. Uit stalmetingen blijkt echter dat er wel $\mathrm{CH}_{4}$ ontstaat. Vergeleken met de emissiefactoren voor reguliere ligboxenstallen (overige huisvesting systemen; A100) blijkt de $\mathrm{NH}_{3}$-emissie voor een vrijloopstal met een bodem van composterende houtsnippers $31 \%$ lager uit te vallen en de emissie van broeikasgassen hoger $\left(\mathrm{CH}_{4}+34 \%\right.$ en $\mathrm{N}_{2} \mathrm{O}$ factor 14) [9]. Galama et al. [8] rapporteren juist een hogere emissie van $\mathrm{NH}_{3}$ en een lagere emissie van $\mathrm{CH}_{4}$. Deze resultaten zijn gebaseerd op metingen uitgevoerd met een fluxkamer in tegenstelling tot de emissiemetingen op stalniveau [9] en in systemen met minder beluchting of andere bodemmaterialen. Wel bevestigen zij ook de veel hogere $\mathrm{N}_{2} \mathrm{O}$-emissies (8-16 keer hoger). Optimalisatie van de beluchting en management om anaerobe plekken te voorkomen kunnen de emissies van broeikasgassen bij vrijloopstallen met een bodem van composterende houtsnippers mogelijk verminderen. Nader onderzoek om dit goed te kwantificeren is echter nog nodig en zal moeten uitwijzen of monitoring en borging van technische of managementmaatregelen haalbaar is.

\subsubsection{Compostering}

Composteren resulteert in grote verliezen aan koolstof $(\mathrm{C})$ en stikstof $(\mathrm{N})$ door aerobe afbraakprocessen. Indien de omstandigheden goed zijn, m.a.w. er voldoende zuurstof aanwezig is, zal 
dit vooral in de vorm van $\mathrm{CO}_{2}$ en $\mathrm{N}_{2}$ gebeuren, maar daarnaast ook in de vorm van $\mathrm{NH}_{3}[6,10]$. Daarnaast zal, ondanks de overwegend aerobe omstandigheden ook $\mathrm{CH}_{4}$-emissie optreden door de hoge temperaturen en het ontstaan van anaerobe zones door de $\mathrm{O}_{2}$ consumptie [6]. Voor de vorming van $\mathrm{N}_{2}$ zijn nitrificatie (aeroob) en denitrificatie (anaeroob) verantwoordelijk. Als een van deze processen niet optimaal verloopt zal $\mathrm{N}_{2} \mathrm{O}$ vorming optreden, vooral tijdens de denitrificatie [10]. Daarnaast zal bij toename van anaerobe zones de $\mathrm{CH}_{4}$-emissie toenemen [6]. Actieve compostering (aerobe opslag) is vanuit het oogpunt van broeikasgasemissies te verkiezen boven passieve compostering (anaerobe opslag) [10, 15]. Indien actieve compostering (van bijvoorbeeld dikke fractie van runder- of varkensmest met pluimveemest) plaatsvindt in gesloten systemen met luchtwassing dan zijn emissies mogelijk gering. Grote risico's op emissies van broeikasgassen treden op bij open compostering en in het bijzonder bij mestvaalten (passieve compostering). Monitoring van composteringsprocessen op boerderijniveau is theoretisch mogelijk (temperatuur, gasconcentraties), maar in de praktijk niet haalbaar door hoge kosten en eisen aan hoe en waar gemeten moet worden.

\subsubsection{Beluchting (dunne fractie)}

Beluchten van de dunne fractie om nitrificatie te stimuleren, gevolgd door een anaerobe fase om denitrificatie te stimuleren wordt in Nederland vooral toegepast in rioolwaterzuiveringsinstallaties en kalvergierzuiveringen. (De mate van beluchting is in dit systeem veel groter dan bij mestmixen met luchtbellen (hoofdstuk 3, deelproject II), waar het doel vooral is om de $\mathrm{CH}_{4}$ - (en $\mathrm{NH}_{3}$-)emissie te reduceren.) In andere landen, bijvoorbeeld België, wordt het ook veel in de varkenshouderij toegepast. Doel van deze maatregel is om $\mathrm{N}$ overschotten weg te werken door omzetting van aanwezige stikstofverbindingen naar het onschadelijke $\mathrm{N}_{2}$. Tijdens de processen van nitrificatie en denitrificatie kunnen echter ook $\mathrm{NH}_{3}, \mathrm{NO}_{x}$ en $\mathrm{N}_{2} \mathrm{O}$ gevormd en kunnen deze stoffen ook emitteren. Uit kalvergierzuiveringsinstallaties ontsnapt $8-13 \%$ van de aanwezige $\mathrm{N}$ als $\mathrm{N}_{2} \mathrm{O}$ [11]. Uit varkensdrijfmest kan tot $20 \%$ van de verwijderde $\mathrm{N}$ ontsnappen als $\mathrm{N}_{2} \mathrm{O}$ [12]. Ondanks hoge beluchtingsniveaus kunnen ook aanzienlijke hoeveelheden $\mathrm{N}_{2} \mathrm{O}$ ontstaan tijdens de nitrificatie, doordat hoge concentraties nitraat het proces belemmeren [12]. Daarnaast zal tijdens de denitrificatie $\mathrm{N}_{2} \mathrm{O}$ ontstaan als het proces door nog aanwezige zuurstof niet volledig verloopt. Aanpassingen in het proces, waaronder cyclische beluchtingsschema's kunnen de $\mathrm{N}_{2} \mathrm{O}$-emissie beperken (tot 3.5\% van verwijderde TAN), maar zeker niet uitsluiten [12]. Naast de gevolgen voor emissies is het ook de vraag in hoeverre deze maatregel gestimuleerd / benut zou moeten worden als aan de andere kant industriële $\mathrm{N}$ fixatie nodig is om kunstmest te maken. Voor de industriële $\mathrm{N}$ fixatie is namelijk (fossiele) energie nodig die ook weer leidt tot broeikasgasemissies. 


\section{$5 \quad$ Effecten in de mestketen}

\section{$5.1 \quad$ Inleiding, doelstelling}

Doel van deelproject IV was het identificeren van kennisleemtes in de mestketen en het formuleren van vervolgstappen om deze kennisleemtes ingevuld te krijgen. Dit ter voorkoming van het verplaatsten van emissierisico's, bijvoorbeeld van stal naar opslag.

Binnen deelproject IV wordt uitgegaan van drijfmest (rundvee en varkens) als basismateriaal, waarbij emissies vanuit de mest in de stal, tijdens eventuele bewerking en in de opslag beschouwd worden. Vaste mest systemen komen in deelproject $V$ (hoofdstuk 6) aan de orde.

\subsection{Resultaat}

Aan de hand van literatuurstudie, uitkomsten van de workshop met experts die gehouden is in het kader van deelproject I (hoofdstuk 2), en nadere consultatie met experts, zijn emissies voor verschillende fases / processtappen beschreven. Op basis hiervan zijn kennisleemtes geïdentificeerd. Naast emissies uit de stal zijn ook de emissies uit de mestopslag (buiten de stal) meegenomen omdat anders mogelijke verplaatsing van emissies niet inzichtelijk gemaakt kan worden.

\subsubsection{Opslag drijfmest (referentie situatie)}

Tijdens de opslag van drijfmest moet vooral rekening gehouden worden met $\mathrm{CH}_{4}$-emissie, aangezien het een anaeroob milieu betreft. Nitrificatie zal daarom nauwelijks optreden en daardoor kan ook geen $\mathrm{N}_{2} \mathrm{O}$ gevormd worden. Als er echter korstvorming optreedt, dan ontstaat daar een aeroob milieu. Dit kan (hypothetisch) zorgen voor verlaging van $\mathrm{CH}_{4}$-emissie doordat methanofiele bacteriën in de korst $\mathrm{CH}_{4}$ oxideren. Tegelijk ontstaat echter ook de mogelijkheid voor nitrificatie in het aerobe milieu en daardoor risico op $\mathrm{N}_{2} \mathrm{O}$-emissie. Dit is o.a. aangetoond in onderzoek van Rhode te al [16].

De vorming van $\mathrm{CH}_{4}$ is vooral afhankelijk van de aanwezigheid van organische stof (energiebron voor bacteriën), aanwezigheid van methanogene bacteriën, zuurstofgehalte, temperatuur, $\mathrm{pH}$ en $\mathrm{NH}_{3}$ concentratie (hoog is toxisch voor methanogene bacteriën) [13]. Maatregelen om deze factoren te beïnvloeden zouden kunnen leiden tot verlaging van de $\mathrm{CH}_{4}$-emissies, waarbij wel gelet moet worden op de effecten op andere emissies, zoals $\mathrm{N}_{2} \mathrm{O}$ en $\mathrm{NH}_{3}$. Opties hiervoor zijn koelen, aanzuren, zouten en beluchten van mest.

Bij beluchten moet rekening gehouden worden met een trade-off door toename van $\mathrm{N}_{2} \mathrm{O}$-emissies, doordat het anaerobe milieu vervangen wordt door een meer aeroob milieu. Deelproject II richt zich met een proef op Dairy Campus specifiek op dit onderdeel, maar resultaten zijn ten tijde van het schrijven van deze rapportage nog niet beschikbaar.

Deens onderzoek [2] heeft aangetoond dat aanzuren een reductie van de $\mathrm{CH}_{4}$-emissie van rond de $70 \%$ kan bewerkstelligen, waarbij tegelijkertijd ook de $\mathrm{NH}_{3}$-emissie afneemt (rond de 60\%) en de $\mathrm{N}_{2} \mathrm{O}$-emissie verwaarloosbaar blijft.

Groenestein et al [17] rapporteren emissiereducties bij koelen van varkensdrijfmest tot $10{ }^{\circ} \mathrm{C}$ van 30 tot $46 \%$ voor verschillende diercategorieën of een reductie van $7 \%$ per ${ }^{\circ} \mathrm{C}$ gebaseerd op de Arrhenius formule uit een modelstudie [18]. Koeling kan bereikt worden door actieve koeling in de mestopslag of door mest uit de stal naar een buiten opslag te verplaatsen. Dit laatste is vooral effectief in varkensstallen waar de temperatuur hoger is dan in rundveestallen.

Kennisleemte: Gegevens over broeikasgasemissies uit (langdurige) drijfmestopslag (in de stal of daarbuiten) na maatregelen zoals koelen, zouten en beluchten zijn zeer beperkt of niet beschikbaar. Hoe kun je zorgen dat de gunstige (emissieremmende) omstandigheden voor langere tijd in stand worden gehouden, oftewel, hoe moet de behandeling voortgezet/herhaald worden? Ook gegevens over emissies bij toediening van behandelde mest zijn niet bekend. Aanvullend onderzoek is nodig 
naar de wisselwerking tussen stal- en opslagemissies en emissies tijdens uitrijden, met onderscheid naar mestsoorten en -producten, waarbij ook seizoenseffecten (als managementmaatregel)

meegenomen kunnen worden. Indien meer $N$ in de mest vastgehouden wordt door maatregelen in de stal of tijdens de opslag, dan is er meer $N$ beschikbaar om te emitteren tijdens uitrijden, waardoor daar de emissies toe kunnen nemen als niet de juiste maatregelen getroffen worden.

\subsubsection{Gescheiden opvang feces en urine}

Bij gebruik van mestbandsystemen of gescheiden mestkanalen in de varkenshouderij worden feces en urine afzonderlijk opgevangen en frequent afgevoerd uit de stal (korte verblijfstijd). Theoretisch zou urease uit de mest niet in contact komen met ureum uit de urine, maar dit lijkt in de praktijk niet helemaal haalbaar. Wel vindt er een aanzienlijke reductie van de $\mathrm{NH}_{3}$-vorming en emissie plaats. Door de korte verblijftijd zal er ook nauwelijks $\mathrm{N}_{2} \mathrm{O}$ - en $\mathrm{CH}_{4}$-emissie optreden in de stal. Voor de opslag van de dunne fractie gelden dezelfde regels als voor drijfmest en kunnen ook dezelfde emissies optreden. De beperkte hoeveelheid organische stof in de dunne fractie zal er echter toe leiden dat er relatief weinig $\mathrm{CH}_{4}$ zal emitteren. De dikke fractie kan verder verwerkt of opgeslagen worden. (zie verder deelproject $\mathrm{V}$, opslag dikke fractie)

Kennisleemte: Gegevens over broeikasgasemissies bij gescheiden opvang zijn zeer beperkt of niet beschikbaar en zijn mogelijk sterk afhankelijk van gekozen systeem en management (hoeveelheid strooisel in stal). Onderzoek en ontwikkeling heeft zich vooral gericht op emissie van $\mathrm{NH}_{3}$ vanuit de stal. De grootste emissies treden echter op tijdens de opslag en toediening van de (dunne en) dikke fractie. Hier is echter geen onderzoek naar bekend.

\subsubsection{Korte verblijftijd drijfmest in stal}

Als drijfmest slechts kort in de stal verblijft en geen oude mest in de kelder achterblijft zullen de processen die verantwoordelijk zijn voor $\mathrm{CH}_{4}$ - en $\mathrm{N}_{2} \mathrm{O}$-emissies niet of nauwelijks op gang komen [13] Achtergebleven oude mest kan echter veel microben bevatten waardoor processen sneller op gang komen. Om het effect van korte verblijftijd daarom te kunnen bereiken is een volledige verwijdering van oude mest noodzakelijk. Hiervoor zijn een beperkt aantal systemen beschikbaar: mestschuif, mestband of mestpannen in de mestkelder.

\subsubsection{Vergisting}

Vergisting vindt plaats in zo goed als mogelijk afgesloten systemen. Aangezien het een anaeroob proces betreft zal er geen sprake zijn van $\mathrm{N}_{2} \mathrm{O}$-emissie [19]. Wel zal $\mathrm{CH}_{4}$-emissie voorkomen door lekkage, maar dit betreft een aanzienlijke reductie ten opzichte van de opslag van niet behandelde drijfmest. Daarnaast is er een indirecte vermindering van broeikasgassen door de productie van energie (vervanging fossiele energie) $[20,21]$.

Holly et al [22] rapporteren een reductie in broeikasgasemissies tijdens opslag en toediening van $25 \%$, waarbij het verminderen van $\mathrm{CH}_{4}$-emissie uit opslag verantwoordelijk was voor het grootste deel van de reductie.

\subsubsection{Opslag digestaat}

Digestaat kan direct opgeslagen worden of verder verwerkt worden. Substraat voor $\mathrm{CH}_{4}$-emissie is tijdens het vergistingsproces al grotendeels verbruikt waardoor emissie van $\mathrm{CH}_{4}$ uit opgeslagen digestaat veel lager is dan uit de niet-behandelde drijfmest (85\% lager [23]). Er zijn echter ook situaties bekend waarbij, in het bijzonder in de zomer, juist meer $\mathrm{CH}_{4}$ uit digestaat emitteert dan uit niet-behandelde drijfmest [16]. Ook in de eerstgenoemde studie is een duidelijke correlatie van $\mathrm{CH}_{4}-$ emissie met de temperatuur van digestaat in de opslag aangetoond [23]. Daarnaast heeft wel mineralisatie van aanwezige $\mathrm{N}$ opgetreden wat kan leiden tot verhoogde $\mathrm{NH}_{3}$-emissie, maar bij opslag onder anaerobe omstandigheden zal $\mathrm{N}_{2} \mathrm{O}$-emissie verwaarloosbaar zijn [19]. Veiligheidseisen aan de opslag van digestaat staan beschreven in een Nederlands Technische Afspraak (NTA 9766). 
Kennisleemte: Gegevens over broeikasgasemissies uit opslag van digestaat zijn zeer beperkt en niet eenduidig. De opslag van digestaat is in grote lijnen vergelijkbaar met de opslag van drijfmest, met uitzondering van de beschikbaarheid van de verschillende substraten (organische stof, gemineraliseerde $N$ ). Deze kennisleemte sluit daarom grotendeels aan bij vragen die spelen rondom de opslag van drijfmest.

\subsubsection{Mestscheiding}

Mestscheiding ${ }^{1}$ vindt meestal plaats in (nagenoeg) gesloten systemen en processen zijn van korte duur. Emissie van $\mathrm{CH}_{4}$ en $\mathrm{N}_{2} \mathrm{O}$ tijdens het proces is daarom verwaarloosbaar. Afhankelijk van de gebruikte techniek ontstaat er een dikke fractie in de vorm van een dikke drab (zeefbocht, trilzeef), een koek (zeefbanden) of een rul product (vijzelpers, centrifuge). Voor emissies uit opslag van de dikke fractie zie verder deelproject $V$.

Daarnaast ontstaat een dunne fractie. Afhankelijk van de hoeveelheid $\mathrm{C}$ in de dunne fractie, moet bij de opslag hiervan rekening gehouden worden met $\mathrm{CH}_{4}$-emissie (vergelijkbaar met drijfmest). Door de anaerobe omstandigheden zal geen $\mathrm{N}_{2} \mathrm{O}$-emissie optreden [19]. Holly et al [22] rapporteren een reductie in broeikasgasemissies van gescheiden mest t.o.v. onbewerkte drijfmest van $31 \%$, waarbij de verminderde $\mathrm{CH}_{4}$-emissie uit opslag verantwoordelijk was voor het grootste deel van de reductie. Melse en Groenestein [19] en Croezen et al [20] daarentegen veronderstellen een gelijkblijvende $\mathrm{CH}_{4-}$ emissie na scheiding, enkel verdeeld over dikke en dunne fractie naar rato van de verdeling van organische stof. Wel moet daarnaast rekening gehouden worden met $\mathrm{N}_{2} \mathrm{O}$-emissie uit de vaste fractie. Dinuccio et al [24] rapporteren een toename van broeikasgasemissies bij gescheiden varkensmest in een kleinschalige opstelling. Emissies uit de dunne fractie waren vergelijkbaar met die uit nietgescheiden mest, maar $\mathrm{N}_{2} \mathrm{O}$-emissies uit de opslag van de dikke fractie was verantwoordelijk voor de toename. Mosquera et al [25] concluderen echter dat de totale broeikasgasemissies van opslag en toedieningen nagenoeg gelijk zullen blijven bij al dan niet scheiden.

Bij scheiding van digestaat werden broeikasgasemissies volgens Holly et al [22] tijdens opslag en toediening niet verder gereduceerd t.o.v. onbewerkt digestaat. De reductie in $\mathrm{CH}_{4}$-emissie werd te niet gedaan door een toename in $\mathrm{N}_{2} \mathrm{O}-\left(\right.$ en $\mathrm{NH}_{3}-$ ) emissie doordat meer $\mathrm{N}$ als $\mathrm{NH}_{4}{ }^{+}$beschikbaar was door mineralisatie tijdens vergisting.

Kennisleemte: Gegevens over broeikasgasemissies uit opslag van dikke en dunne fracties na mestscheiding, al dan niet na vergisting, zijn zeer beperkt en niet eenduidig. Ook gegevens over invloed van gebruikte scheidingstechniek op broeikasgasemissies zijn niet beschikbaar. Zolang deze kennis ontbreekt, wordt stimuleren van mestscheiding afgeraden.Standaardtekst Standaardtekst

\footnotetext{
${ }^{1}$ Het betreft hier scheiding van drijfmest (achteraf), dus niet gescheiden opvang van mest en urine.
} 


\section{$6 \quad$ Vaste mest}

\subsection{Inleiding, doelstelling}

Vaste mest heeft betrekking op pluimveemest, zowel strooiselmest als (gedroogde) bandmest, mest uit strohuisvesting voor o.a. varkens en rundvee en de dikke fractie na mestscheiding van varkens- en rundveemest. Uit vaste mest kunnen, afhankelijk van de omstandigheden en gebruikte technieken, $\mathrm{CH}_{4}, \mathrm{~N}_{2} \mathrm{O}$ en $\mathrm{NH}_{3}$ emitteren. In het algemeen kan gesteld worden dat effecten van maatregelen bij vaste mest moeilijker zijn in te schatten dan bij drijfmest, mede omdat weinig (kwantitatieve) onderzoeksgegevens beschikbaar zijn [26].

Doel van dit deelproject is te inventariseren welke emissies uit verschillende opslagsystemen voor vaste mest, zowel in de stal als daarbuiten, plaats vinden en welke kennis nodig is om maatregelen te formuleren om deze emissies te voorkomen.

\subsection{Resultaat}

\subsubsection{Melkvee}

Systemen met vaste mest in de melkveehouderij zijn slechts beperkt aanwezig, aangezien de overgrote meerderheid drijfmestsystemen zijn. Potstallen en vrijloopstallen zijn besproken in deelproject III, waar ze als risicovolle maatregel zijn bestempeld. Opslag van mest uit deze systemen elders op het bedrijf zal slechts beperkt voorkomen, aangezien beide staltypen periodiek leeggehaald moeten worden en de mest dan meestal direct, of na een beperkte opslagduur, uitgereden wordt.

\subsubsection{Varkens}

Vaste mest bij varkens komt hoofdzakelijk voor bij groepshuisvesting van guste en dragende zeugen in een rondloopstal met zeugenvoerstation en strobed (RAV D1.3.10). Deze zijn ook besproken in deelproject III, waar ze als risicovolle maatregel zijn bestempeld. Opslag van mest uit dit systeem elders op het bedrijf zal slechts beperkt voorkomen, aangezien dit systeem periodiek leeggehaald wordt en de mest dan meestal direct, of na een beperkte opslagduur, uitgereden wordt.

\subsubsection{Pluimvee}

Pluimveemest is eigenlijk altijd vaste mest. Enige uitzondering in de RAV zijn batterijkooien met drijfmestopslag. Deze komen echter in Nederland niet meer voor. Binnen de pluimveemest kan onderscheid gemaakt worden tussen strooiselmest, mest onder de roosters in een mestput (beide langdurig in de stal aanwezig) en de mest die onder roosters op mestbanden terecht komt (frequent afgevoerd uit de stal). Daarnaast is er onderscheid naar diercategorie. Bij vleeskuikens en opfok vleeskuikenouderdieren is sprake van grondhuisvesting waarbij alle mest in het strooisel terecht komt. Bij (opfok-)legkippen in volièrehuisvesting komt een deel in het strooisel terecht en wordt het merendeel frequent afgevoerd via de mestbanden. Bij (opfok-)legkippen in grondhuisvesting (traditioneel scharrel) en vleeskuikenouderdieren komt ook een deel in het strooisel terecht, maar het merendeel in de mestput onder de roosters (de beun).

Voor strooiselmest is mogelijk vloerkoeling (BWL 2001.11.V3) een methode om emissies te beperken, hoewel dit voor $\mathrm{CH}_{4}$ en $\mathrm{N}_{2} \mathrm{O}$ nog niet met meetresultaten ondersteunt kan worden. Daarmee is er onvoldoende grond om dit systeem te stimuleren.

Een methode die toegepast wordt voor $\mathrm{NH}_{3}$-emissiereductie is extra stalrecirculatie van lucht (BWL 2005.10.V6, mixluchtventilatie). Effecten op $\mathrm{N}_{2} \mathrm{O}$-emissies zijn echter ook hier niet bekend en zouden mogelijk nadelig uit kunnen pakken als een anaerobe onderlaag gecombineerd wordt met een door droging meer aerobe bovenlaag. Metingen van broeikasgasemissies bij dit systeem zijn ook niet bekend. 
Voor bandmest zijn snelle verwijdering uit de stal en droging effectieve maatregelen tegen stalemissies. Pluimveemest heeft als voordeel dat $\mathrm{N}$ vastligt in urinezuur en niet in ureum. Voor de afbraak van urinezuur is meer tijd nodig, waardoor minder snel $\mathrm{NH}_{4}{ }^{+}$beschikbaar komt, wat weer de grondstof is voor nitrificatie en denitrificatie. Frequent afvoeren van mest uit de stal en snel drogen tot $>80 \%$ droge stof kan $\mathrm{NH}_{3}$-emissie substantieel reduceren omdat $\mathrm{NH}_{4}{ }^{+}$-vorming wordt voorkomen. En daarmee is tegelijk ook de directe bron voor $\mathrm{N}_{2} \mathrm{O}$-emissie aangepakt. Daarnaast zal het lage vochtgehalte ook tot gevolg hebben dat nagenoeg alle microbiële activiteit verdwijnt, wat ook gunstig is voor reductie van overige emissies, met uitzondering van fijn stof.

Het alleen voordrogen in de stal, op de mestbanden middels beluchting, resulteert in mest met een droge stofgehalte van 40-50\%. Hiermee worden bacteriële processen niet stilgelegd en mogelijk zelfs versterkt. Daarnaast zal het drogere oppervlak meer aeroob zijn, hetgeen $\mathrm{N}_{2} \mathrm{O}$-emissie kan bevorderen. Frequente afvoer en adequate opslag, bijvoorbeeld in gesloten containers, zijn dan ook zeker van belang.

\subsubsection{Opslag van vaste mest (incl. dikke fractie na mestscheiding)}

Mest met een droge stofgehalte van boven de $80 \%$ kan zonder veel emissie van $\mathrm{NH}_{3}, \mathrm{~N}_{2} \mathrm{O}$ en $\mathrm{CH}_{4}$ opgeslagen worden, aangezien microbiële processen nagenoeg stil liggen.

Vaste mest met lagere droge stof gehaltes, al dan niet met strooisel, maar waar nog wel sprake is van een rul product, zal bij opslag gaan broeien, oftewel passief composteren, met daarbij behorende emissies van $\mathrm{NH}_{3}, \mathrm{~N}_{2} \mathrm{O}$ en $\mathrm{CH}_{4}$ (zie ook deelproject 3 waar compostering als risicovolle maatregel besproken is). De enige maatregel die hier zinvol lijkt is het afdekken van de mestopslag [6, 15], omdat daarmee het oplopen van de temperatuur voorkomen kan worden en de beschikbaarheid van zuurstof beperkt wordt. Bij lagere temperaturen verlopen alle chemische en microbiële processen langzamer, en daarmee verminderen de emissies van $\mathrm{NH}_{3}, \mathrm{~N}_{2} \mathrm{O}$ en $\mathrm{CH}_{4}$. Daarnaast kan beperking van de beschikbaarheid van zuurstof leiden tot verdere vermindering van de $\mathrm{N}_{2} \mathrm{O}$-emissie [6]. Het verhogen van de dichtheid van mesthoop, verlaagt wel de temperatuur en $\mathrm{NH}_{3}$-emissie, maar verhoogt de $\mathrm{N}_{2} \mathrm{O}$-emissie en heeft geen effect op de $\mathrm{CH}_{4}$-emissie [6].

Dikke fractie na scheiding in de vorm van een koek (zeefbanden) zal minder en in de vorm van drab (zeefbocht, trilzeef) zal (bijna) geen $\mathrm{N}_{2} \mathrm{O}$-emissie voortbrengen gezien de meer anaerobe omstandigheden. Emissie van $\mathrm{CH}_{4}$ kan hierdoor wel toenemen.

\subsection{Discussie / conclusie}

Kwantitatieve gegevens betreffende emissies van broeikasgassen uit vaste mest zijn niet of nauwelijks beschikbaar, waardoor een modelmatige aanpak van effecten in de mestketen niet haalbaar is. Ook effecten van maatregelen in de ene fase op emissies in volgende fases zijn niet of slechts zeer beperkt bekend. Aanvullend onderzoek, zowel op het gebied van metingen als modelontwikkeling, is hier gewenst, waarbij ook effecten bij uitrijden meegenomen moeten worden. 


\section{$7 \quad$ Implementatie in Klimaatlat}

De resultaten van deze deelprojecten I-V hebben geleid tot de uitwerking van enkele reducerende maatregelen die in de Klimaatlat van de MDV opgenomen kunnen worden (deelproject VI). Er is slecht een beperkt aantal maatregelen praktijkrijp, maar door het opnemen van deze maatregelen wordt bewustwording en verdere ontwikkeling van maatregelen gestimuleerd. De maatregelen, inclusief controlerichtlijnen, zijn opgenomen in bijlage 1 .

\section{Overwegingen}

Er zijn een aantal principiële keuzes gemaakt voordat $\mathrm{CH}_{4}$ - en $\mathrm{N}_{2} \mathrm{O}$ reducerende maatregelen in de MDV opgenomen konden worden:

- De MDV was gericht op de stal en de mestopslag buiten de stal werd buiten beschouwing gelaten. De opslag buiten de stal moet echter meegenomen worden, omdat anders verplaatsing van emissies niet inzichtelijk gemaakt kan worden.

- In ieder geval worden no-regret maatregelen gestimuleerd, uitbreiding van het aantal maatregelen volgt later. Dit speelt bijvoorbeeld bij stalsystemen waarbij de mest sneller uit het dierverblijf wordt verwijderd. Als er daarna geen emissiearme opslag of mestverwerking plaatsvindt, dan zou snelle mestverwijdering alleen een verplaatsing van de broeikasgasemissies betekenen. Echter, dit soort stalsystemen vormen een randvoorwaarde om (in de toekomst) mestverwerking toe te passen.

- De criteria zijn nog beperkt tot broeikasgasemissies uit drijfmestsystemen.

- Verder is het ambitieniveau voor de klimaatlat herijkt, door een weging tussen energiemaatregelen $\left(\mathrm{CO}_{2}\right)$ en overige broeikasgassen $\left(\mathrm{CH}_{4}\right.$ en $\left.\mathrm{N}_{2} \mathrm{O}\right)$ te maken in de vorm van $\mathrm{CO}_{2}$-equivalenten voor elke diercategorie.

Een integrale aanpak van $\mathrm{NH}_{3}$ - en $\mathrm{CH}_{4}$-emissie is vooralsnog niet haalbaar. $\mathrm{De} \mathrm{CH}_{4}$-reducerende maatregelen hebben ook een verbinding met $\mathrm{NH}_{3}$-reductie die beperkend werkt:

- Varkens: de systemen die $\mathrm{NH}_{3}$-emissie aan de bron reduceren, reduceren ook de $\mathrm{CH}_{4}$-emissie uit de stal. Echter dit zijn systemen die op zichzelf niet voldoen aan de wettelijke normen voor $\mathrm{NH}_{3}$-emissie en zouden daardoor altijd gecombineerd moeten worden met een end-of-pipe techniek om $\mathrm{NH}_{3}$-emissie te reduceren. Vooralsnog is er in de MDV geen verplichting opgenomen om $\mathrm{NH}_{3}$ en $\mathrm{CH}_{4}$-emissie integraal aan te pakken, omdat het aantal systemen waarmee dat gerealiseerd kan worden te beperkt is.

- Melkvee: 4 van de 12 systemen die $\mathrm{NH}_{3}$-emissie aan de bron reduceren, reduceren ook $\mathrm{CH}_{4}$ emissie uit de stal. Dit betreft stalsystemen met een (volledig) dichte vloer en mestopvangputten met een beperkte capaciteit. Deze systemen hebben een $\mathrm{NH}_{3}$-emissie van 8,0 tot 8,3 en voldoen daarmee niet aan de $\mathrm{NH}_{3}$-emissienormen die in de provincie NoordBrabant worden gesteld. Hier is dus sprake van een tegenstelling in reduceren van $\mathrm{NH}_{3}$ en $\mathrm{CH}_{4}$. Het onderzoek dat loopt naar mestkoeling, in een melkveestal met roostervloer, biedt in de toekomst wellicht perspectief om $\mathrm{NH}_{3}$ en $\mathrm{CH}_{4}$ integraal aan te pakken in melkveestallen.

\section{Wachtkamermaatregelen}

Een aantal maatregelen worden voorlopig nog niet opgenomen omdat kwantitatieve gegevens betreffende emissies van broeikasgassen niet of nauwelijks beschikbaar zijn. Hierdoor is een modelmatige aanpak niet haalbaar en zijn effecten van maatregelen in de ene fase, op emissies in volgende fases niet of slechts zeer beperkt bekend. Aanvullend onderzoek, zowel op het gebied van metingen als modelontwikkeling, is hier gewenst.

- Mestmixen met luchtbellen (opgenomen in deelproject 2, oplevering verwacht in 2020).

- Vaste mest stalsystemen en opslag:

- Vloerkoeling in pluimveehouderij

- Frequente afvoer strooisel en mest uit pluimveestallen. Frequent afvoeren van mest uit de stal (meerdere keren per dag afdraaien mestband) en snel drogen tot $>80 \%$ droge stof voorkomt vorming $\mathrm{N}_{2} \mathrm{O}$. (Het voordrogen in de stal, op de mestbanden middels beluchting, voldoet niet omdat de bacteriële processen niet worden stilgelegd.) 
- Opslag vaste mest buiten de stal.

In een emissiearme mestopslag vinden minder $\mathrm{N}_{2} \mathrm{O}$-emissies plaats als deze afgedekt is uitgevoerd. Het afdekken voorkomt het oplopen van de temperatuur en beperkt de beschikbaarheid van zuurstof, waardoor alle chemische en microbiële processen langzamer verlopen.

- Opslag dikke fractie na scheiding.

Opslag van dikke fractie na scheiding met zeefbanden, zeefbocht, of trilzeef zal (bijna) geen $\mathrm{N}_{2} \mathrm{O}$-emissie voortbrengen. Methaanemissie is hier wel een aandachtspunt

- Emissiearme potstal en vrijloopstallen.

Indien het strooiselpakket droog en aeroob is (en anaerobe omstandigheden vermeden worden) kunnen $\mathrm{CH}_{4}$ - en $\mathrm{N}_{2} \mathrm{O}$-emissies beperkt blijven.

- Biofiltratie

- Turffilter

- Methaanoxidatie in bodem 


\section{Schematisch weergave bevindingen en aanbevelingen}

In dit hoofdstuk is een schematisch overzicht gegeven van de resultaten van de deelprojecten, afgezet tegen de verschillende stal- en opslagsystemen (Figuur 8.1). Daarnaast is in tabellen 8.1 en 8.2 aangegeven waarvan $\mathrm{CH}_{4}$ - en $\mathrm{N}_{2} \mathrm{O}$-vorming afhankelijk zijn, wat het effect is van die parameter en waarop gestuurd kan worden. Tot slot is aangegeven hoe deze resultaten toegepast kunnen worden in de Klimaatlat en in beleidskeuzes.

Referentie:
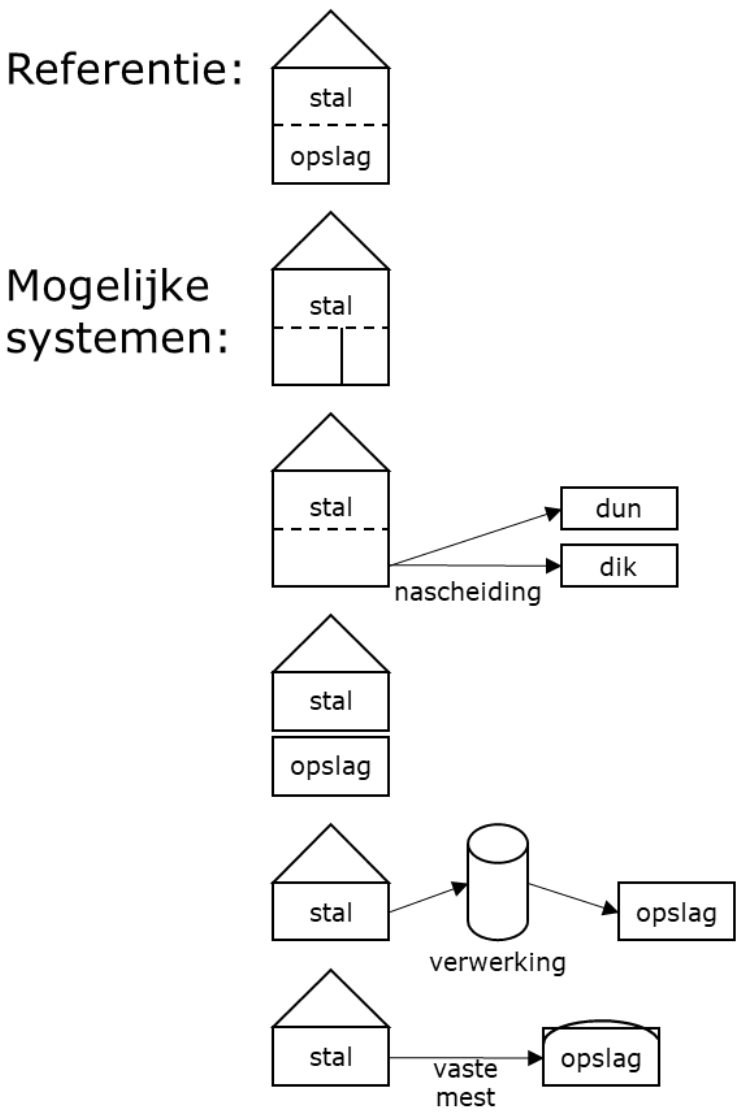

Mestopslag in dierenverblijf, zonder sturing op parameters

Stal met directe scheiding mest en urine, waarbij urine verder als 'drijfmest' en mest als 'vaste mest' in de opslag wordt behandeld

Voor dunne en dike fractie bij nascheiding geldt ook: verder opslag als 'drijfmest' en 'vaste mest'

Snelle afvoer drijfmest uit dierverblijf en opslag onder of buiten de stal

Snelle afvoer drijfmest uit dierverblijf, gevolgd door verwerkingsstap en opslag

Afgedekte opslag voor stalsystemen met vaste mest

Figuur 8.1 Schematisch overzicht mogelijke systemen.

Tabel 8.1 Parameters waarvan methaan $\left(\mathrm{CH}_{4}\right)$-vorming afhankelijk is, het effect van de parameter en mogelijkheid tot sturing.

\begin{tabular}{lll} 
CH4-vorming afhankelijk van: & Effect parameter & In opslag sturen op: \\
Organische stof & Energiebron bacteriën & $\begin{array}{l}\text { Managementmaatregelen voerspoor } \\
\text { of gebruik strooiselmaterialen }\end{array}$ \\
\hline Methanogene bacteriën & $\begin{array}{l}\text { Laag gehalte vertraagt } \\
\text { vormingsproces }\end{array}$ & $\begin{array}{l}\text { Snelle afvoer en voorkomen } \\
\text { achterblijven resten in mestopslag. }\end{array}$ \\
\hline Zuurstofgehalte & Zuurstof vertraagt vormingsproces & Let op: wisselwerking met $\mathrm{N}_{2} \mathrm{O}$. \\
\hline Temperatuur & $\begin{array}{l}\text { Lage temperatuur vertraagt } \\
\text { microbiële processen }\end{array}$ & Koelen mest \\
\hline Zuurgraad & Lage pH (zuur) vertraagt & Aanzuren mest \\
\hline $\mathrm{NH}_{3}$-concentratie & vormingsproces & \\
\hline
\end{tabular}


Tabel 8.2 Parameters waarvan lachgas $\left(\mathrm{N}_{2} \mathrm{O}\right)$-vorming afhankelijk is, het effect van de parameter en mogelijkheid tot sturing.

\begin{tabular}{|c|c|c|}
\hline $\mathrm{N}_{2} \mathrm{O}$-vorming afhankelijk van: & Effect parameter & In opslag sturen op: \\
\hline Zuurstofgehalte & $\begin{array}{l}\text { Zuurstof nodig voor vormingsproces, } \\
\text { maar ook gebrek aan zuurstof }\end{array}$ & $\begin{array}{l}\text { Afdekken } \\
\text { Let op: wisselwerking met } \mathrm{CH}_{4} \text {. }\end{array}$ \\
\hline Temperatuur & $\begin{array}{l}\text { Lage temperatuur vertraagt } \\
\text { microbiële processen }\end{array}$ & Koelen mest \\
\hline Drogestofgehalte van vaste mest & $\begin{array}{l}\text { Laag vochtgehalte }(\mathrm{DM}>80 \%) \\
\text { verlaagt microbiële activiteit }\end{array}$ & Drogen mest \\
\hline Stikstofgehalte & Grondstof voor vormingsproces & $\begin{array}{l}\text { Managementmaatregelen voerspoor } \\
\text { of gebruik strooiselmaterialen }\end{array}$ \\
\hline
\end{tabular}

De resultaten van de deelprojecten hebben geleid tot de uitwerking van enkele emissiereducerende maatregelen die zijn opgenomen in de Klimaatlat van de MDV voor rundvee- en varkensstallen. De MDV is een instrument waarmee hardware in stallen gestimuleerd kan worden. Wellicht is het zinvol om broeikasgas emissiereducerende maatregelen ook apart te stimuleren, zodat voorlopende ondernemers een extra beloning kunnen krijgen voor het uitvoeren van deze maatregelen.

Er zijn een aantal maatregelen/systemen benoemd die beter niet gestimuleerd kunnen worden uit oogpunt van broeikasgasemissies. Hier zitten ook stalsystemen bij die vanuit dierenwelzijn juist wel gestimuleerd worden. Het is goed als het beleid steeds meer gericht wordt op integratie van thema's, zoals broeikasgassen, $\mathrm{NH}_{3}$ en dierenwelzijn.

De inzichten in kennisleemtes bieden perspectief om op korte termijn de nodige informatie te verkrijgen om voor de langere termijn beleidskeuzes te maken.

De implementatie in de klimaatlat van de MDV betreft hardware maatregelen. Er zijn ook diverse managementmaatregelen waarvoor een borging uitgewerkt kan worden, bijvoorbeeld in aansluiting op sectormonitoring in het kader van al bestaande marktconcepten (bijv. IKB). 


\section{Literatuur}

1. Keuper, D., C. Rougoor, and F. Van der Schans, Klimaatmaatregelen in MDV. 2017, CLM Onderzoek en Advies: Culemborg, the Netherlands.

2. Sommer, S.G., T.J. Clough, N. Balaine, S.D. Hafner, and K.C. Cameron, Transformation of Organic Matter and the Emissions of Methane and Ammonia during Storage of Liquid Manure as Affected by Acidification. Journal of Environmental Quality, 2017. 46(3): p. 514-521.

3. Van Dooren, H.J.C., S. Bokma, and N.W.M. Ogink, Ammoniakemissie tijdens frequent mixen van drijfmestmet lucht: Onderzoek op Dairy Campus. 2019, Wageningen Livestock Research: Wageningen, the Netherlands.

4. Calvet, S., J. Hunt, and T.H. Misselbrook, Low frequency aeration of pig slurry affects slurry characteristics and emissions of greenhouse gases and ammonia. Biosystems Engineering, 2017. 159: p. 121-132.

5. Feiken, M. and W. Van Laarhoven, Verslag van een praktijkonderzoek naar het gebruik van vaste fractie uit gescheiden mest als boxbedekkingsmateriaal in ligboxen voor melkvee. 2012, ValaconDairy v.o.f.: Sint-Oedenrode.

6. Webb, J., S.G. Sommer, T. Kupper, K. Groenestein, N.J. Hutchings, B. Eurich-Menden, L. Rodhe, T.H. Misselbrook, and B. Amon, Emissions of Ammonia, Nitrous Oxide and Methane During the Management of Solid Manures, in Agroecology and Strategies for Climate Change, E. Lichtfouse, Editor. 2012, Springer Netherlands: Dordrecht. p. 67-107.

7. Pijlman, J., G.J. Monteny, and J. De Wit, Strooiselstalsystemen: ammoniak en andere emissies, dierwelzijn en mestkwaliteit. 2018, Louis Bolk Instituut: Bunnik. p. 57.

8. Galama, P.J., H.C. De Boer, H.J. Van Dooren, W. Ouweltjes, and F. Driehuis, Sustainability aspects of ten bedded pack dairy barns in The Netherlands. 2015, Wageningen UR Livestock Research: Wageningen.

9. Van Dooren, H.J.C., J.M.G. Hol, K. Blanken, and P.J. Galama, Gasvormige emissies uit vrijloopstallen met houtsnipperbodems : ammoniak-, lachgas- en methaanemissie op stalniveau. 2019, Wageningen Livestock Research: Wageningen. p. 50.

10. Amon, B., T. Amon, J. Boxberger, and C. Alt, Emissions of NH3, N2O and CH4 from dairy cows housed in a farmyard manure tying stall (housing, manure storage, manure spreading). Nutrient Cycling in Agroecosystems, 2001. 60(1): p. 103-113.

11. Burton, C.H., C. Turner, and I. Silsoe Research, Manure management : treatment strategies for sustainable agriculture. 2nd ed. / ed. 2003, Silsoe: Silsoe Research Institute.

12. Pahl, O., C.H. Burton, W. Dunn, and A.J. Biddlestone, The source and abatement of nitrous oxide emissions produced from the aerobic treatment of pig slurry to remove surplus nitrogen. Environ Technol, 2001. 22(8): p. 941-50.

13. Mosquera, J. and J.M.G. Hol, Emissiefactoren methaan, lachgas en PM2,5 voor stalsystemen, inclusief toelichting = Emission factors for methane, nitrous oxide and PM2.5 for livestock housing, including explanation. 2011, Wageningen UR Livestock Research: Lelystad.

14. Mosquera, J., J.M.G. Hol, and J.W.H. Huis in 't Veld, Onderzoek naar de emissies van een natuurlijk geventileerde potstal voor melkvee I, Stal. 2005, Wageningen: Agrotechnology \& Food Innovations.

15. Mosquera, J., C.M. Groenestein, M. Timmerman, A.J.A. Aarnink, and A. Winkel, Deskstudie naar maatregelen ter vermindering van broeikasgasemissies uit varkens- en pluimveestallen = Desk study on measures to reduce greenhouse gas emissions from pig and poultry houses. 2013, Wageningen UR Livestock Research: Lelystad.

16. Rodhe, L.K.K., J. Ascue, A. Willén, B.V. Persson, and $\AA$. Nordberg, Greenhouse gas emissions from storage and field application of anaerobically digested and non-digested cattle slurry. Agriculture, Ecosystems \& Environment, 2015. 199: p. 358-368.

17. Groenestein, K., J. Mosquera, and S. Van der Sluis, Emission factors for methane and nitrous oxide from manure management and mitigation options. Journal of Integrative Environmental Sciences, 2012. 9(sup1): p. 139-146.

18. Sommer, S.G., S.O. Petersen, and H.B. Møller, Algorithms for calculating methane and nitrous oxide emissions from manure management. Nutrient Cycling in Agroecosystems, 2004. 69(2): p. 143154.

19. Melse, R.W. and C.M. Groenestein, Emissiefactoren mestbewerking : inschatting van emissiefactoren voor ammoniak en lachgas uit mestbewerking. 2016, Wageningen UR Livestock Research: Wageningen. 
20. Croezen, H.J., J.T.W. Vroonhof, J.A.G. Frijns, E.H.M. Van Zundert, R.J.H.L. Van Os, A.J.F. Brinkmann, R.W. Melse, H.V.M. Hamelers, and A.H.M. Veeken, TEWI-benadering mestbewerking en -verwerking : eindrapport. 2003, Grontmij Water \& Reststoffen: De Bilt.

21. Baral, K.R., G. Jégo, B. Amon, R. Bol, M.H. Chantigny, J.E. Olesen, and S.O. Petersen, Greenhouse gas emissions during storage of manure and digestates: Key role of methane for prediction and mitigation. Agricultural Systems, 2018. 166: p. 26-35.

22. Holly, M.A., R.A. Larson, J.M. Powell, M.D. Ruark, and H. Aguirre-Villegas, Greenhouse gas and ammonia emissions from digested and separated dairy manure during storage and after land application. Agriculture, Ecosystems \& Environment, 2017. 239: p. 410-419.

23. Maldaner, L., C. Wagner-Riddle, A.C. VanderZaag, R. Gordon, and C. Duke, Methane emissions from storage of digestate at a dairy manure biogas facility. Agricultural and Forest Meteorology, 2018. 258: p. 96-107.

24. Dinuccio, E., P. Balsari, and W. Berg, GHG emissions during the storage of rough pig slurry and the fractions obtained by mechanical separation. Australian Journal of Experimental Agriculture, 2008. 48(2).

25. Mosquera, J., R. Schils, C.M. Groenestein, P. Hoeksma, G.L. Velthof, and E. Hummelink, Emissies van lachgas, methaan en ammoniak uit mest na scheiding (in Dutch). 2010, Wageningen UR Livestock Research: Wageningen, the Netherlands.

26. Groenestein, C.M., J.F.M. Huijsmans, and R.L.M. Schils, Emissies van broeikasgassen, ammoniak, fijn stof en geur in de mestketen (in Dutch). 2010, Wageningen UR Livestock Research,:

Wageningen, the Netherlands. p. 39. 



\section{Bijlage 1 Definitieve Klimaatmaatregelen MDV}

De volgende maatregelen om $\mathrm{CH}_{4}$-emissie te reduceren zijn in de Klimaatlat voor melkveestallen opgenomen.

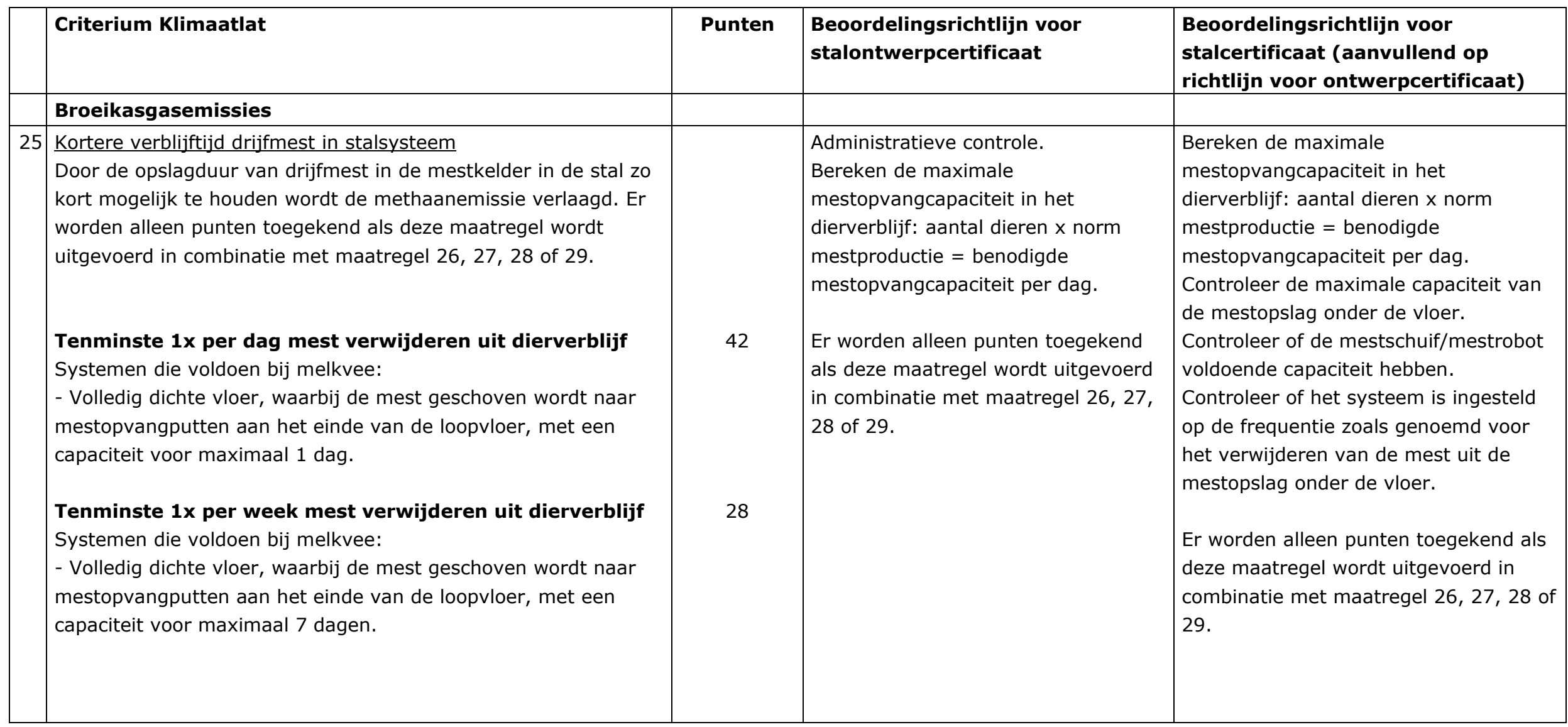




\begin{tabular}{|c|c|c|c|c|}
\hline & $\begin{array}{l}\text { Tenminste 1x per maand mest verwijderen uit dierverblijf } \\
\text { Systemen die voldoen bij melkvee: } \\
\text { - Volledig dichte vloer, waarbij de mest geschoven wordt naar } \\
\text { mestopvangputten aan het einde van de loopvloer, met een } \\
\text { capaciteit voor maximaal } 14 \text { dagen. } \\
\text { De norm voor mestproductie is } 0,07 \mathrm{~m}^{3} \text { per koe per dag. } \\
\text { Opmerking: Bij het toepassen van een dichte vloer is de } \\
\text { beloopbaarheid een aandachtspunt. Mogelijke opties om dit te } \\
\text { voorkomen, bijvoorbeeld door de vloer nat te houden, voldoende } \\
\text { profilering of rubber op de vloer, zijn in de dierenwelzijnsmaatlat } \\
\text { opgenomen. }\end{array}$ & 23 & & \\
\hline 26 & $\begin{array}{l}\text { Vergistingsinstallatie } \\
\text { Opvangen van methaan en gebruiken in een vergister levert een } \\
\text { emissiereductie van methaan op. Daarnaast wordt energie } \\
\text { (biogas, elektriciteit en/of warmte) opgewekt die energie uit } \\
\text { fossiele bronnen kan vervangen. } \\
\text { De installatie en bijbehorende voorzieningen voldoen aan de } \\
\text { volgende eisen: } \\
\text { - Het betreft een monovergister die op het bedrijf aanwezig is. } \\
\text { De vergister bestaat uit een gasdichte, verwarmde en/of } \\
\text { geroerde tank of mestzak. } \\
\text { - De mest wordt na afvoer uit het dierverblijf rechtstreeks naar } \\
\text { de mestvergister gevoerd. Een tussenopslag is niet toegestaan. } \\
\text { Voorbehandeling is wel toegestaan. } \\
\text { - de mest uit de vergister gaat via een tijdelijke naopslag (waar } \\
\text { de laatste vergistingsgassen uit de mest vrijkomen) naar een } \\
\text { eindopslag voor digestaat. } \\
\text { - Vergistingsgassen uit de vergister en tijdelijke naopslag } \\
\text { worden opgevangen en naar een gasbehandelingsinstallatie } \\
\text { gevoerd. }\end{array}$ & 14 & $\begin{array}{l}\text { Administratieve controle van het type } \\
\text { vergister. }\end{array}$ & $\begin{array}{l}\text { Controleer administratief en fysiek aan } \\
\text { de hand van het type vergister of er } \\
\text { sprake is van een monovergister die } \\
\text { werkt op volledige mest input. } \\
\text { Controleer visueel of er geen } \\
\text { tussenopslag aanwezig is tussen het } \\
\text { dierverblijf en de mestvergister. } \\
\text { Controleer administratief of een vifjarig } \\
\text { onderhoudscontract is afgesloten. } \\
\text { Controleer of een NTA } 9766 \text { verklaring } \\
\text { door onafhankelijke instelling is } \\
\text { ingevuld. } \\
\text { Stel vast of de naopslag is uitgevoerd } \\
\text { conform het criterium. }\end{array}$ \\
\hline
\end{tabular}




\begin{tabular}{|c|c|c|c|c|}
\hline & $\begin{array}{l}\text { - de vergistingsinstallatie en bijbehorende voorzieningen voldoen } \\
\text { aan NTA } 9766 . \\
\text { - Er is een onderhoudscontract voor tenminste } 5 \text { jaar afgesloten, } \\
\text { waarbij een deskundige partij tenminste éénmaal per jaar } \\
\text { controle en onderhoud van de mestvergister met alle } \\
\text { bijbehorende voorzieningen uitvoert. } \\
\text { - Het digestaat wordt opgeslagen in een naopslag die voldoet } \\
\text { aan de eisen in criterium } 5 \text {, of het digestaat wordt } \\
\text { gehygiëniseerd conform EG } 1069 / 2009 \text { (d.m.v. aanzuren). } \\
\text { Definitie digestaat: mestproduct dat overblijft na mestvergisting. }\end{array}$ & & & \\
\hline 27 & $\begin{array}{l}\text { Koeling drijfmest in opslag } \\
\text { Een lagere mesttemperatuur remt het methaanvormingsproces, } \\
\text { waardoor de methaanemissie wordt gereduceerd. } \\
\text { Systemen die voldoen bij alle diercategorieën met drijfmest: } \\
\text { - Gekoelde opslag van drijfmest. } \\
\text { Mesttemperatuur blijft onder: } \\
\text { - } 10 \text { graden } \\
\text { - } 5 \text { graden } \\
\text { Warmte-koude-opslag voldoet niet aan dit criterium. }\end{array}$ & $\begin{array}{c}7 \\
14\end{array}$ & Administratieve controle & $\begin{array}{l}\text { Stel vast of de opslag van drijfmest is } \\
\text { uitgevoerd conform het criterium. }\end{array}$ \\
\hline 28 & $\begin{array}{l}\text { Aanzuren van drijfmest in opslag } \\
\text { Een lage pH-waarde remt het methaanvormingsproces, } \\
\text { waardoor de methaanemissie wordt gereduceerd. } \\
\text { Drijfmest wordt aangezuurd opgeslagen en voldoet aan de } \\
\text { volgende voorwaarden: } \\
\text { - mestopslag bevindt zich onder of buiten de stal en is geschikt } \\
\text { voor opslag aangezuurde mest (gemaakt van een glad, } \\
\text { corrosiebestendig en niet-hechtend materiaal, zoals roestvrij } \\
\text { staal of kunststof). }\end{array}$ & 14 & Administratieve controle & $\begin{array}{l}\text { Controleer visueel of mestopslag in } \\
\text { aangezuurde vloeistof plaatsvindt. } \\
\text { Controleer visueel of de zuurvoorraad is } \\
\text { opgeslagen conform } \\
\text { veiligheidsvoorschriften in de } \\
\text { vergunning. } \\
\text { Controleer op aanwezigheid en } \\
\text { functioneren pH-meting, door middel } \\
\text { van de registratie van de afgelopen } \\
\text { maand. }\end{array}$ \\
\hline
\end{tabular}




\begin{tabular}{|c|c|c|c|c|}
\hline & $\begin{array}{l}\text { - zuurvoorraad wordt opgeslagen conform vergunning. } \\
\text { - zuurdosering automatisch op basis van } \mathrm{pH} \text {-meting van de mest } \\
\text { in de opslag. De automatische dosering is voorzien van een } \\
\text { registratiemogelijkheid van de } \mathrm{pH} \text { waarden van de mest in de } \\
\text { opslag. } \\
\text { - de zuurgraad van de mest in de opslag moet kleiner dan of } \\
\text { gelijk zijn aan } 5,5 \text {. } \\
\text { - er is een doseersysteem geïnstalleerd waarmee automatisch } \\
\text { meer zuur wordt gedoseerd zodra de zuurgraad boven } 5,5 \mathrm{pH} \\
\text { komt. } \\
\text { - voor het aanzuren van de mestvloeistof dient gebruik te } \\
\text { worden gemaakt van één van de volgende zuren: } \\
\text { - Calprona (dit is een mengsel van zuivere zuren), } \\
\text { - MMDBA (mixed mono and dibasic acids), of } \\
\text { - AMGUARD (dit is een mengsel van diverse zuren. } \\
\text { - er is een onderhoudscontract afgesloten voor tenminste } 5 \text { jaar, } \\
\text { waarbij een deskundige partij tenminste éénmaal per jaar } \\
\text { controle en onderhoud van het mestbehandelingsproces met alle } \\
\text { bijbehorende voorzieningen uitvoert. }\end{array}$ & & & $\begin{array}{l}\text { Controleer administratief of het zuur in } \\
\text { de voorraad voldoet aan de norm. } \\
\text { Controleer aanwezigheid en inhoud } \\
\text { onderhoudscontract. }\end{array}$ \\
\hline 29 & $\begin{array}{l}\text { Emissiearme mestopslag } \\
\text { In een emissiearme mestopslag vinden minder methaanemissies } \\
\text { plaats als deze gasdicht is uitgevoerd, met een gasafvang bij de } \\
\text { overdrukbeveiliging. } \\
\text { De mestslag dient te voldoen aan de volgende voorwaarden: } \\
\text { - De mestopslag bevindt zich buiten de stal. } \\
\text { - Is gasdicht uitgevoerd met een overdrukbeveiliging die voldoet } \\
\text { aan het Activiteitenbesluit. } \\
\text { - Ontstane gassen in de gasdichte ruimte worden opgevangen. } \\
\text { - Er is een buffercapaciteit van tenminste } 4 \text { uur gasproductie om } \\
\text { het gas tijdens een technische storing op te vangen. }\end{array}$ & 14 & Administratieve controle & $\begin{array}{l}\text { Stel vast of de opslag van drijfmest } \\
\text { buiten het dierverblijf is uitgevoerd } \\
\text { conform het criterium. }\end{array}$ \\
\hline
\end{tabular}


- $\mathrm{Er}$ is een vaste fakkelinstallatie die voldoet aan de

veiligheidseisen NPR 7910-1+C1 om ongewenste emissies van

gassen te voorkomen.

- Meet-, regel- en drukbeveiligingssystemen moeten worden

ingeregeld zodat wordt ingegrepen bij afwijkingen in het proces.

De volgende maatregelen om $\mathrm{CH}_{4}$-emissie te reduceren zijn in de Klimaatlat voor varkensstallen opgenomen:

\begin{tabular}{|c|c|c|c|c|}
\hline & Criterium Klimaatlat & Punten & $\begin{array}{l}\text { Beoordelingsrichtlijn voor } \\
\text { stalontwerpcertificaat }\end{array}$ & $\begin{array}{l}\text { Beoordelingsrichtlijn voor } \\
\text { stalcertificaat (aanvullend op richtlijn } \\
\text { voor ontwerpcertificaat) }\end{array}$ \\
\hline & Broeikasgasemissies & & & \\
\hline 33 & $\begin{array}{l}\text { Kortere verblijftijd drijfmest in stalsysteem } \\
\text { Door de opslagduur van drijfmest in de mestkelder in de stal zo } \\
\text { kort mogelijk te houden wordt de methaanemissie verlaagd. Er } \\
\text { worden alleen punten toegekend als deze maatregel wordt } \\
\text { uitgevoerd in combinatie met maatregel } 34,35,36 \text { of } 37 . \\
\text { Tenminste 1x per dag mest verwijderen uit dierverblijf } \\
\text { Systemen die voldoen bij varkens: } \\
\text { - Mestband in kelder (D1.3.15) tweemaal daags mestafvoer. } \\
\text { - Spoelen met ammoniakarme vloeistof en aanzuren (D3.2.2) } \\
\text { Indien éénmaal per dag gespoeld wordt met dunne fractie } \\
\text { (BB93.06.010, BB93.11.011, BWL 2001.24.V1 systeem } 1 \text { en 3). } \\
\text { Tenminste 1x per week mest verwijderen uit dierverblijf } \\
\text { Systemen die voldoen bij varkens: } \\
\text { - Met mestpannen (D1.2.13, D1.2.14) Eénmaal per drie dagen } \\
\text { mestafvoer. } \\
\text { - Spoelgotensysteem (D1.1.6, D1.1.7, D1.2.8, D1.3.3, D1.3.4, } \\
\text { D3.2.12, D3.2.13) Eénmaal per } 2 \text { dagen spoelen met dunne } \\
\text { fractie. }\end{array}$ & $\begin{array}{l}24 \\
\\
16\end{array}$ & $\begin{array}{l}\text { Administratieve controle. } \\
\text { Bereken de maximale } \\
\text { mestopvangcapaciteit in het } \\
\text { dierverblijf: aantal dieren x norm } \\
\text { mestproductie = benodigde } \\
\text { mestopvangcapaciteit per dag. }\end{array}$ & $\begin{array}{l}\text { Bereken de maximale } \\
\text { mestopvangcapaciteit in het dierverblijf: } \\
\text { aantal dieren x norm mestproductie = } \\
\text { benodigde mestopvangcapaciteit per dag. } \\
\text { Controleer de maximale capaciteit van de } \\
\text { mestopslag onder de vloer. } \\
\text { Controleer of de mestschuif/mestrobot } \\
\text { voldoende capaciteit hebben. } \\
\text { Controleer of het systeem is ingesteld op } \\
\text { de frequentie zoals genoemd voor het } \\
\text { verwijderen van de mest uit de } \\
\text { mestopslag onder de vloer. }\end{array}$ \\
\hline
\end{tabular}




\begin{tabular}{|c|c|c|c|c|}
\hline & $\begin{array}{l}\text { - Spoelen met ammoniakarme vloeistof en aanzuren (D3.2.2) } \\
\text { Indien éénmaal per } 3 \text { dagen gespoeld wordt met dunne fractie } \\
\text { (BB93.11.011/A95.04.024 en BWL 2001.24.V1 systeem 2). } \\
\text { Tenminste 1x per maand mest verwijderen uit dierverblijf } \\
\text { Systemen die voldoen bij varkens: } \\
\text { - Schuine putwand (D1.3.9) Eénmaal per twee weken } \\
\text { mestafvoer uit mestkanaal. } \\
\text { - Mestopvang in water of ammoniakarme vloeistof (D3.2.5). Er } \\
\text { worden alleen punten toegekend als de capaciteit van de } \\
\text { mestopvang maximaal gelijk is aan de norm mestproductie } \\
\text { voor } 1 \text { maand. } \\
\text { De norm voor mestproductie is } 0,0137 \mathrm{~m}^{3} \text { per zeug per dag. } \\
\text { Extra } \\
\text { De mestkelder onder het dierverblijf wordt regelmatig gereinigd } \\
\text { d.m.v. een mestschuif, mestband of mestpannen in de } \\
\text { mestkelder. }\end{array}$ & 13 & & \\
\hline 34 & $\begin{array}{l}\text { Vergistingsinstallatie } \\
\text { Opvangen van methaan en gebruiken in een vergister levert } \\
\text { een emissiereductie van methaan op. Daarnaast wordt energie } \\
\text { (biogas, elektriciteit en/of warmte) opgewekt die energie uit } \\
\text { fossiele bronnen kan vervangen. } \\
\text { De installatie en bijbehorende voorzieningen voldoen aan de } \\
\text { volgende eisen: } \\
\text { - Het betreft een monovergister die op het bedrijf aanwezig is. } \\
\text { De vergister bestaat uit een gasdichte, verwarmde en/of } \\
\text { geroerde tank of mestzak. } \\
\text { - De mest wordt na afvoer uit het dierverblijf rechtstreeks naar } \\
\text { de mestvergister gevoerd. Een tussenopslag is niet toegestaan. } \\
\text { Voorbehandeling is wel toegestaan. }\end{array}$ & 8 & $\begin{array}{l}\text { Administratieve controle van het } \\
\text { type vergister. }\end{array}$ & $\begin{array}{l}\text { Controleer administratief en fysiek aan de } \\
\text { hand van het type vergister of er sprake is } \\
\text { van een monovergister die werkt op } \\
\text { volledige mest input. } \\
\text { Controleer visueel of er geen tussenopslag } \\
\text { aanwezig is tussen het dierverblijf en de } \\
\text { mestvergister. } \\
\text { Controleer administratief of een vijfjarig } \\
\text { onderhoudscontract is afgesloten. } \\
\text { Controleer of een NTA } 9766 \text { verklaring } \\
\text { door onafhankelijke instelling is ingevuld. } \\
\text { Stel vast of de naopslag is uitgevoerd } \\
\text { conform het criterium. }\end{array}$ \\
\hline
\end{tabular}




\begin{tabular}{|c|c|c|c|c|}
\hline & $\begin{array}{l}\text { - de mest uit de vergister gaat via een tijdelijke naopslag (waar } \\
\text { de laatste vergistingsgassen uit de mest vrijkomen) naar een } \\
\text { eindopslag voor digestaat. } \\
\text { - Vergistingsgassen uit de vergister en tijdelijke naopslag } \\
\text { worden opgevangen en naar een gasbehandelingsinstallatie } \\
\text { gevoerd. } \\
\text { - de vergistingsinstallatie en bijbehorende voorzieningen } \\
\text { voldoen aan NTA } 9766 \text {. } \\
\text { - Er is een onderhoudscontract voor tenminste } 5 \text { jaar } \\
\text { afgesloten, waarbij een deskundige partij tenminste éénmaal } \\
\text { per jaar controle en onderhoud van de mestvergister met alle } \\
\text { bijbehorende voorzieningen uitvoert. } \\
\text { - Het digestaat wordt opgeslagen in een naopslag die voldoet } \\
\text { aan de eisen in criterium } 5 \text {, of het digestaat wordt } \\
\text { gehygiëniseerd conform EG } 1069 / 2009 \text { (d.m.v. aanzuren). } \\
\text { Definitie digestaat: mestproduct dat overblijft na } \\
\text { mestvergisting. }\end{array}$ & & & \\
\hline 35 & $\begin{array}{l}\text { Koeling drijfmest in opslag } \\
\text { Een lagere mesttemperatuur remt het methaanvormingsproces, } \\
\text { waardoor de methaanemissie wordt gereduceerd. } \\
\text { Systemen die voldoen bij alle diercategorieën met drijfmest: } \\
\text { - Gekoelde opslag van drijfmest buiten het dierverblijf. } \\
\text { Mesttemperatuur blijft onder: } \\
\text { - } 10 \text { graden } \\
\text { - } 5 \text { graden } \\
\text { Andere systemen die voldoen bij varkens (zonder koppeling aan } \\
\text { kortere verblijftijd in stalsysteem): } \\
\text { - Koeldeksysteem (D1.3.8.2, D3.2.3, D3.2.6) } \\
\text { - Gekoelde mestpannen bij kraamzeugen (D1.2.20) }\end{array}$ & $\begin{array}{l}4 \\
8\end{array}$ & Administratieve controle & $\begin{array}{l}\text { Stel vast of de opslag van drijfmest is } \\
\text { uitgevoerd conform het criterium. }\end{array}$ \\
\hline
\end{tabular}




\begin{tabular}{|c|c|c|c|c|}
\hline & Warmte-koude-opslag in de mest voldoet niet aan dit criterium. & & & \\
\hline 36 & $\begin{array}{l}\text { Aanzuren van drijfmest in opslag } \\
\text { Een lage pH-waarde remt het methaanvormingsproces, } \\
\text { waardoor de methaanemissie wordt gereduceerd. } \\
\text { Drijfmest wordt aangezuurd opgeslagen en voldoet aan de } \\
\text { volgende voorwaarden: } \\
\text { - mestopslag bevindt zich onder of buiten de stal en is geschikt } \\
\text { voor opslag aangezuurde mest (gemaakt van een glad, } \\
\text { corrosiebestendig en niet-hechtend materiaal, zoals roestvrij } \\
\text { staal of kunststof). } \\
\text { - zuurvoorraad wordt opgeslagen conform vergunning. } \\
\text { - zuurdosering automatisch op basis van pH-meting van de } \\
\text { mest in de opslag. De automatische dosering is voorzien van } \\
\text { een registratiemogelijkheid van de pH waarden van de mest in } \\
\text { de opslag. } \\
\text { - de zuurgraad van de mest in de opslag moet kleiner dan of } \\
\text { gelijk zijn aan 5,5. } \\
\text { - er is een doseersysteem geïnstalleerd waarmee automatisch } \\
\text { meer zuur wordt gedoseerd zodra de zuurgraad boven } 5,5 \mathrm{pH} \\
\text { komt. } \\
\text { - voor het aanzuren van de mestvloeistof dient gebruik te } \\
\text { worden gemaakt van één van de volgende zuren: } \\
\text { - Calprona (dit is een mengsel van zuivere zuren), } \\
\text { - MMDBA (mixed mono and dibasic acids), of } \\
\text { - AMGUARD (dit is een mengsel van diverse zuren. } \\
\text { - er is een onderhoudscontract afgesloten voor tenminste } 5 \\
\text { jaar, waarbij een deskundige partij tenminste éénmaal per jaar } \\
\text { controle en onderhoud van het mestbehandelingsproces met } \\
\text { alle bijbehorende voorzieningen uitvoert. }\end{array}$ & 8 & Administratieve controle & $\begin{array}{l}\text { Stel vast of de opslag van drijfmest buiten } \\
\text { het dierverblijf is uitgevoerd conform het } \\
\text { criterium. } \\
\text { Controleer visueel of mestopslag in } \\
\text { aangezuurde vloeistof plaatsvindt. } \\
\text { Controleer visueel of de zuurvoorraad is } \\
\text { opgeslagen conform } \\
\text { veiligheidsvoorschriften in de vergunning. } \\
\text { Controleer op aanwezigheid en } \\
\text { functioneren pH-meting, door middel van } \\
\text { de registratie van de afgelopen maand. } \\
\text { Controleer administratief of het zuur in de } \\
\text { voorraad voldoet aan de norm. } \\
\text { Controleer aanwezigheid en inhoud } \\
\text { onderhoudscontract. }\end{array}$ \\
\hline
\end{tabular}




\begin{tabular}{|c|c|c|c|c|}
\hline 37 & $\begin{array}{l}\text { Emissiearme mestopslag } \\
\text { In een emissiearme mestopslag vinden minder } \\
\text { methaanemissies plaats als deze gasdicht is uitgevoerd, met } \\
\text { een gasafvang bij de overdrukbeveiliging. } \\
\text { De mestslag dient te voldoen aan de volgende voorwaarden: } \\
\text { - De mestopslag bevindt zich buiten de stal. } \\
\text { - Is gasdicht uitgevoerd met een overdrukbeveiliging die } \\
\text { voldoet aan het Activiteitenbesluit. } \\
\text { - Ontstane gassen in de gasdichte ruimte worden opgevangen. } \\
\text { - Er is een buffercapaciteit van tenminste } 4 \text { uur gasproductie } \\
\text { om het gas tijdens een technische storing op te vangen. } \\
\text { - Er is een vaste fakkelinstallatie die voldoet aan de } \\
\text { veiligheidseisen NPR } 7910-1+\text { C1 om ongewenste emissies van } \\
\text { gassen te voorkomen. } \\
\text { - Meet-, regel- en drukbeveiligingssystemen moeten worden } \\
\text { ingeregeld zodat wordt ingegrepen bij afwijkingen in het } \\
\text { proces. }\end{array}$ & 8 & Administratieve controle & $\begin{array}{l}\text { Stel vast of de opslag van drijfmest buiten } \\
\text { het dierverblijf is uitgevoerd conform het } \\
\text { criterium. }\end{array}$ \\
\hline
\end{tabular}





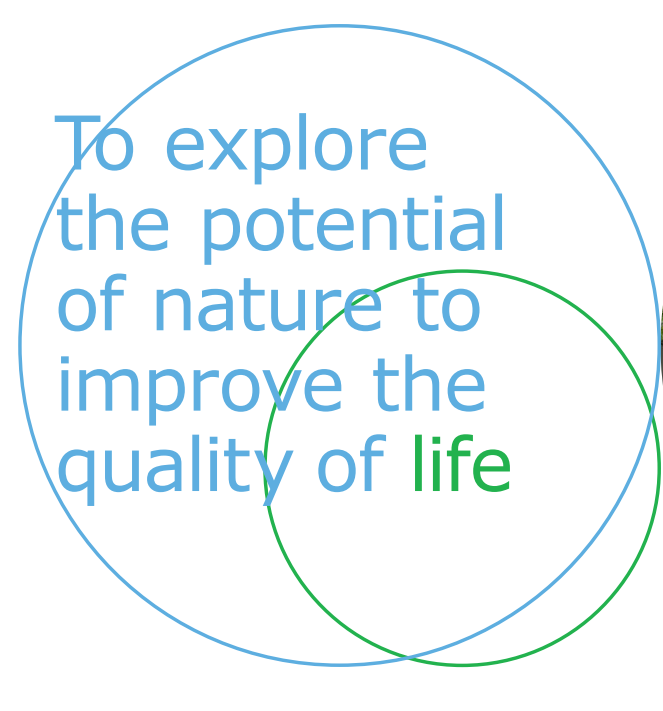

Wageningen Livestock Research Postbus 338

6700 AH Wageningen

T 0317483953

E info.livestockresearch@wur.nl www.wur.nl/livestock-research

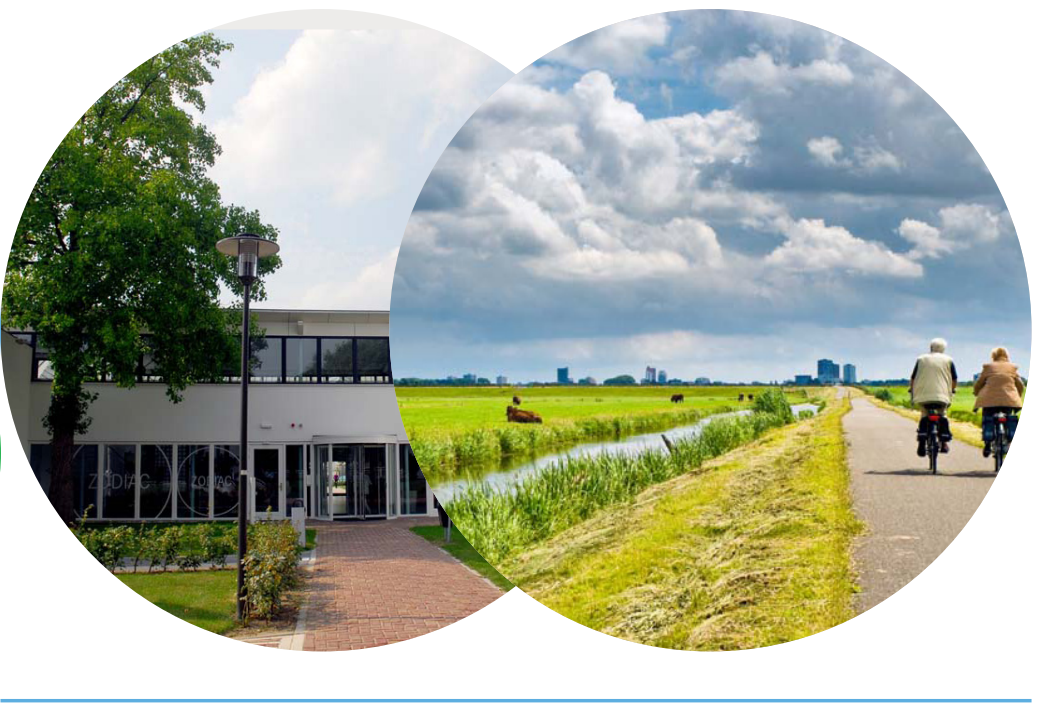

Wageningen Livestock Research ontwikkelt kennis voor een zorgvuldige en renderende veehouderij, vertaalt deze naar praktijkgerichte oplossingen en innovaties, en zorgt voor doorstroming van deze kennis. Onze wetenschappelijke kennis op het gebied van veehouderijsystemen en van voeding, genetica, welzijn en milieu-impact van landbouwhuisdieren integreren we, samen met onze klanten, tot veehouderijconcepten voor de 21 e eeuw.

De missie van Wageningen University \& Research is 'To explore the potential of nature to improve the quality of life'. Binnen Wageningen UR bundelen 9 gespecialiseerde onderzoeksinstituten van stichting DLO en Wageningen University hun krachten om bij te dragen aan de oplossing van belangrijke vragen in het domein van gezonde voeding en leefomgeving. Met ongeveer 30 vestigingen, 6.000 medewerkers en 10.000 studenten behoort Wageningen UR wereldwijd tot de aansprekende kennisinstellingen binnen haar domein. De integrale benadering van de vraagstukken en de samenwerking tussen verschillende disciplines vormen het hart van de unieke Wageningen aanpak. 